\title{
PREZENTACE ARCHEOLOGICKÝCH PAMÁTEK V ČECHÁCH. ARCHEOLOGICKÉ AREÁLY IN SITU - PŘÍKLADY Z PRAŽSKÉHO HRADU A VYŠEHRADU
}

\author{
IVANA BOHÁČOVÁ
}

\begin{abstract}
Abstrakt: Prezentace archeologických památek na dvou prvořadých pražských lokalitách - na Pražském hradě (1929) a Vyšehradě (1934) - náleži k nejstarším svého typu i v evropském měrítku. Oba areály spojuje nejen jejich význam z hlediska mimoŕádnosti památek, které uchovávají, a z hlediska historie památkové péče o nemovité kulturni dědictví, ale rovněž skutečnost, že jsou i v současnosti zdrojem nových poznatků výjimečné důležitosti. Oba areály prošly z iniciativy ARÚ AV ČR, Praha, v. v. i., v posledních letech sanací. Ta zabezpečila jejich dalši existenci a současně umožnila i nové využití jejich výpovédního potenciálu. Součástí sanace bylo i stanoveni základniho režimu ochrany areálio, spočivajicí zejména v návrhu zajištění dřve chybéjícího pravidelného monitoringu stavu památek a prostredí, a tedy preventivního nebo alespoň včasného řšeni možné degradace areáli̊.
\end{abstract}

Kličová slova: archeologická rezervace - památková péče - Praha-prezentace in situ - raný středověkkamenná architektura-dřevěné stavby.

Presentation of Archaeological Monuments in Bohemia. Archaeological complexes in situ-examples from Prague Castle and Vyšehrad

\begin{abstract}
Presentations of archaeological monuments on two prime Prague sites, Prague Castle (1929) and Vyšehrad (1934), belong with the earliest of their kind in the European context. Both complexes are significant in terms of the uniqueness of their contents and in terms of heritage care for cultural monuments, as well as for the fact that even today the sites remain sources of new information of special importance. On the initiative of the Institute of Archaeology, of the CAS, Prague, v. v. i., the complexes have been reconstructed in recent years. The reconstruction has ensured their further existence and, at the same time, enables new usage of their information potential. The reconstruction involved the determination of a basic mode of the protection of similar complexes rooted in a proposal to launch previously lacking regular monitoring of the state of the monuments and their environment, and thus provide preventive or at least early solutions to the possible dilapidation of such complexes.
\end{abstract}

Key words: archaeological reserve - heritage care - Prague - in situ presentation - early Middle Ages stone architecture - wooden buildings.

\section{Areál pod třetím nádvořím Pražského hradu a areál s bazilikou sv. Vavřince na Vyšehra- dě - charakter a význam}

Prvorepubliková archeologie středověku nám zanechala unikátní odkaz v podobě nejstarších archeologických areálů in situ. Vznikly v souvislosti se záchrannými výzkumy na Pražském hradě (III. nádvoř́i 1925-1929 - K. Guth, J. Pasternak a kol.) a Vyšehradě (areál s bazilikou sv. Vavřince 1924-1926 - J. Böhm, M. Grbić; souběžně i další dílčí prezentace odkrytých památek). Areál pod III. nádvořím Pražského hradu a areál s bazilikou sv. Vavřince na Vyšehradě jsou přes svou rozdílnou rozlohu unikátními příklady památkové ochrany a prezentace významných archeologických památek $\mathrm{v}$ měřítku celoevropském. Jejich podstatou byla 1) stabilizace vybraných archeologických objektů in situ, ve výjimečných př́padech pak i jejich vyjmutí in situ a přemístění (obr. 1), 2) snaha o uchování a prezentaci širšího nálezového prostorového, v případě Pražského hradu i stratigrafického kontextu těchto památek, 3) šetrné nakládání s archeologickými objekty (minimalizace destruktivních zásahů, minimalizace konzervačních zásahů), 4) snaha o zprostředkování autentického vjemu široké i odborné veřejnosti, 5) profesionalita a mezioborová kooperace (technické řešení s využitím nejmodernějších dobově dostupných postupů a zkušeností erudovaných odborníků). Přitom si oba areály dosud uchovávají výjimečný informační potenciál pro další výzkum, a to včetně výzkumu interdisciplinárního. Více než 


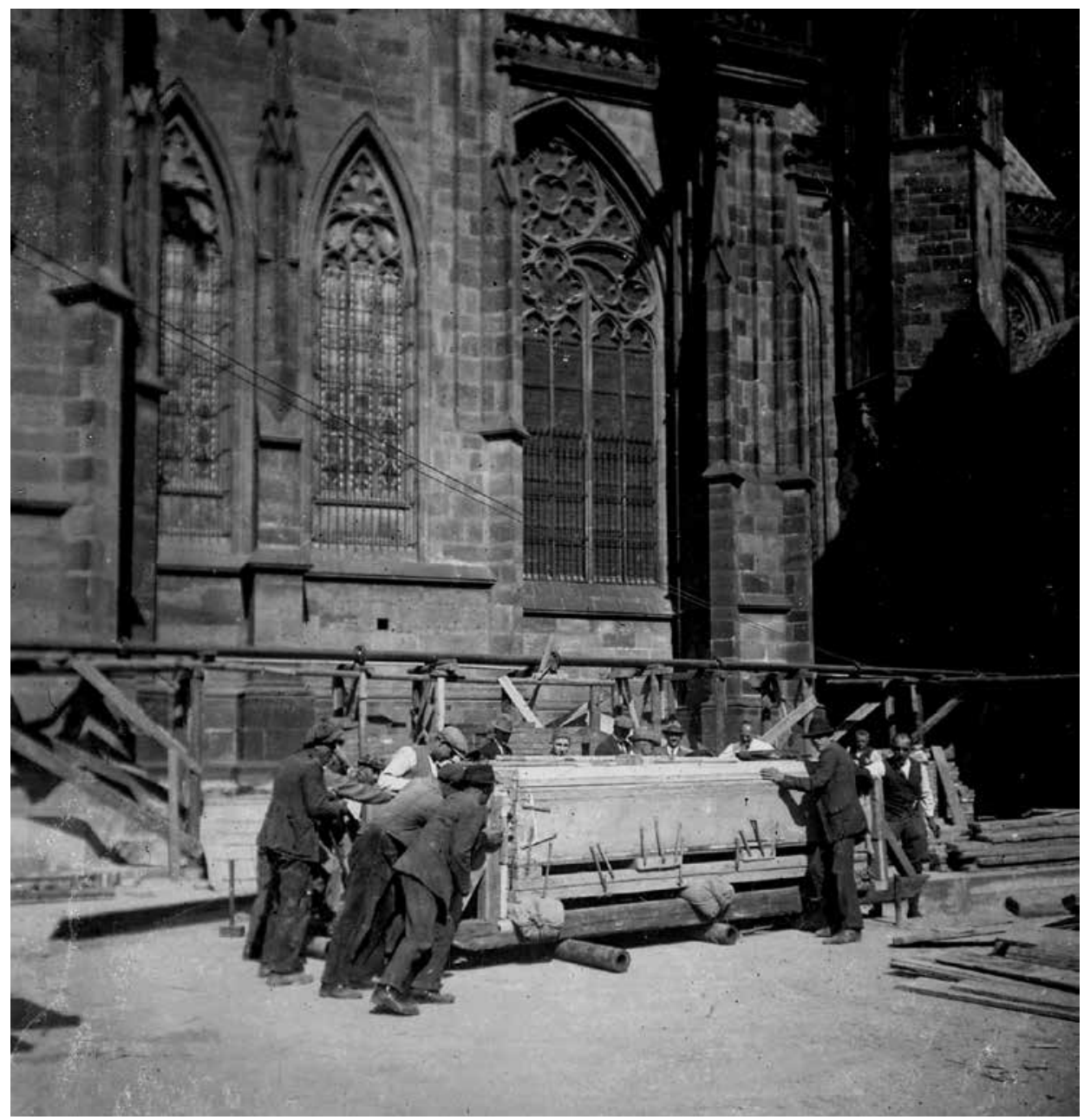

Obr. 1. Pražský hrad, III. nádvoří. Transport hrobu muže s mečem, sekerou a dalšími předměty hrobové výbavy - tzv. bojovníka, objeveného v jihozápadní části III. nádvoří společně s dalšími pohřby. ARÚ AV ČR, Praha, FT000103901.

Abb. 1. Prager Burg, III. Burghof. Abtransport des Grabes eines Mannes - ein sog. Kriegergrab - mit Schwert, Beil und weiteren Grabbeigaben, das zusammen mit weiteren Gräbern im südwestlichen Teil des III. Burghofs entdeckt wurde. Archäologisches Institut der Akademie der Wissenschaften der Republik Tschechien, Prag, FT000103901.

osmdesátiletá existence obou areálů a zejména takřka „bezúdržbové“ období druhé poloviny 20. století byly $\mathrm{v}$ obou př́ípadech podnětem pro projekty jejich sanace (III. nádvoří 1997-1998, sv. Vavřinec 2010-2011), které zajistily jejich existenci pro další desetiletí (obr. 2, 3) a současně přinesly, díky realizovanému reviznímu výzkumu spojenému se sanačními pracemi a také díky využití dříve nedostupných exaktních analýz některých druhů pramenů, řadu nových poznatků zcela zásadního významu.

\section{Areál pod třetím nádvořím Pražského hradu}

\subsection{Souvislosti vzniku}

Areál vznikl v souvislosti s rekonstrukcí Pražského hradu na sídlo prvého československého prezidenta Tomáše G. Masaryka v návaznosti na plošný archeologický záchranný výzkum 


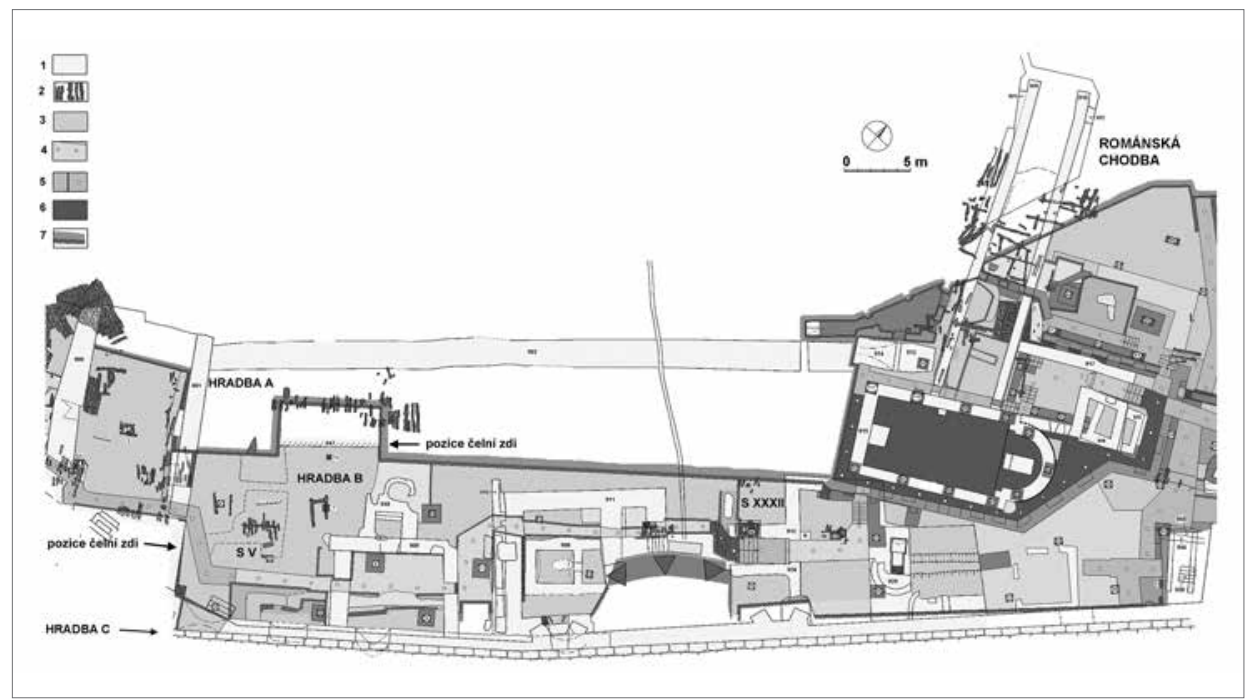

Obr. 2. Pražský hrad, areál pod III. nádvořím. Prostor tzv. velkých vykopávek s vyznačením typů uchovávaných a pokryvných materiálů (Boháčová 2008, obr. 1). 1 - zdiva, 2 - dřevěné konstrukce, 3 - terény; novodobé úpravy: 4 - zpevněná komunikační trasa, 5 - beton / betonová komunikační trasa, 6 - dlažba, 7 - hranice př́istupného prostoru. Šedé čtverce s čísly označují nosné pilíře železobetonové desky. Grafické vyhotovení plánu v rámci projektu sanace - firma PERES 1998 v programu Corel.

Abb. 2. Prager Burg, Areal unter dem III. Burghof (sog. große Ausgrabungen) mit Kennzeichnung des jeweiligen Typs der erhaltenen Materialien und Deckmaterialien (Boháčová 2008, Abb. 1). 1 - Mauerwerk, 2 - Holzkonstruktionen, 3 - Gelände; neuzeitliche Herrichtungen: 4 - befestigte Wegetrasse, 5 - Beton / Betonwegetrasse, 6 - Pflasterung, 7 - Grenze des zugänglichen Bereichs. Die mit Ziffern versehenen grauen Vierecke bezeichnen die Tragepfeiler der Eisenbetonplatte. Die Planskizze wurde im Rahmen des Sanierungsprojekts von der Firma PERES 1998 mit der Software Corel grafisch erstellt.

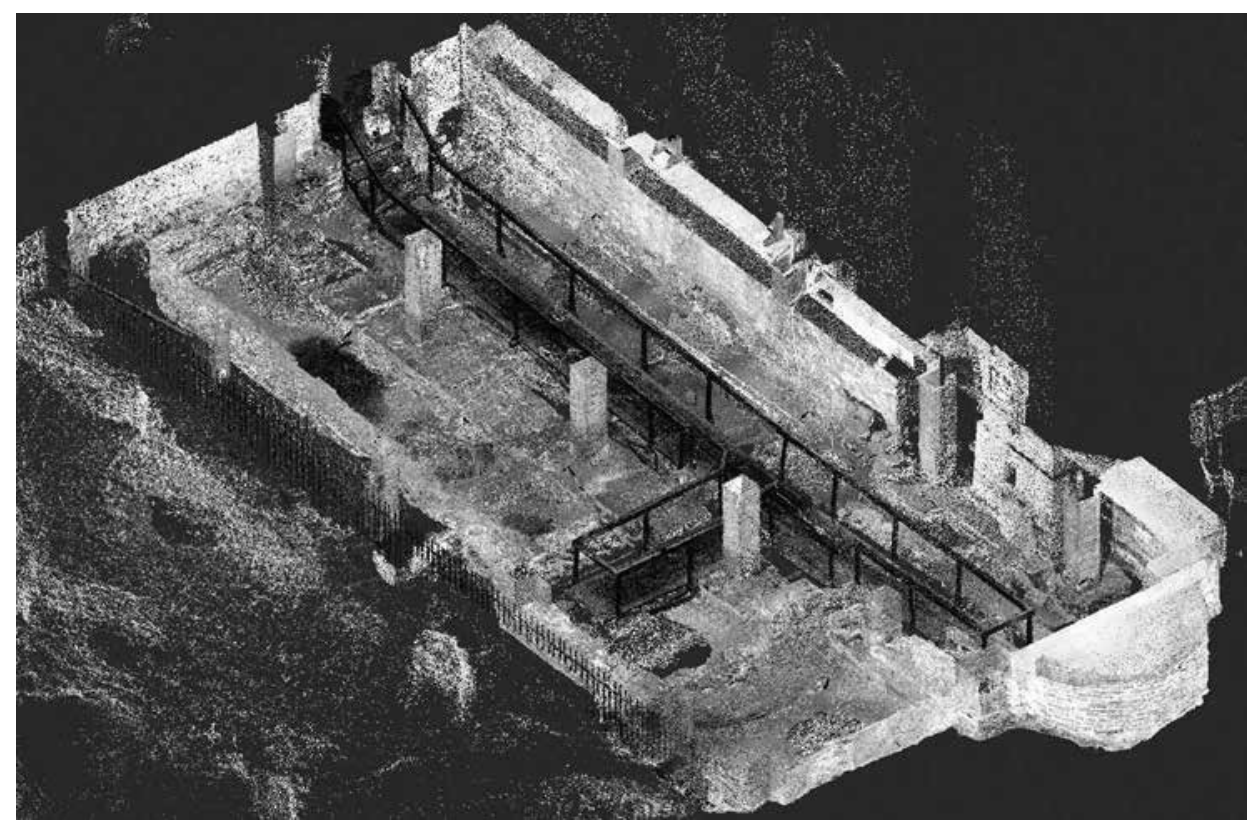

Obr. 3. Praha - Vyšehrad, areál s bazilikou sv. Vavřince. Stav reliktů staveb a situace přirozeného terénu po vybrání novodobých zásypů. Dokumentace 3D Z. Marek (scaner Farao) v rámci projektu sanace 2011.

Abb. 3. Prag - Vyšehrad, Areal mit St. Laurentius-Basilika. Zustand der Gebäuderelikte und der Situation des natürlichen Geländes nach Aushub der neuzeitlichen Verfüllungen. 3D-Dokumentation Z. Marek (FARO Laserscanner) im Rahmen des Sanierungsprojekts von 2011. 


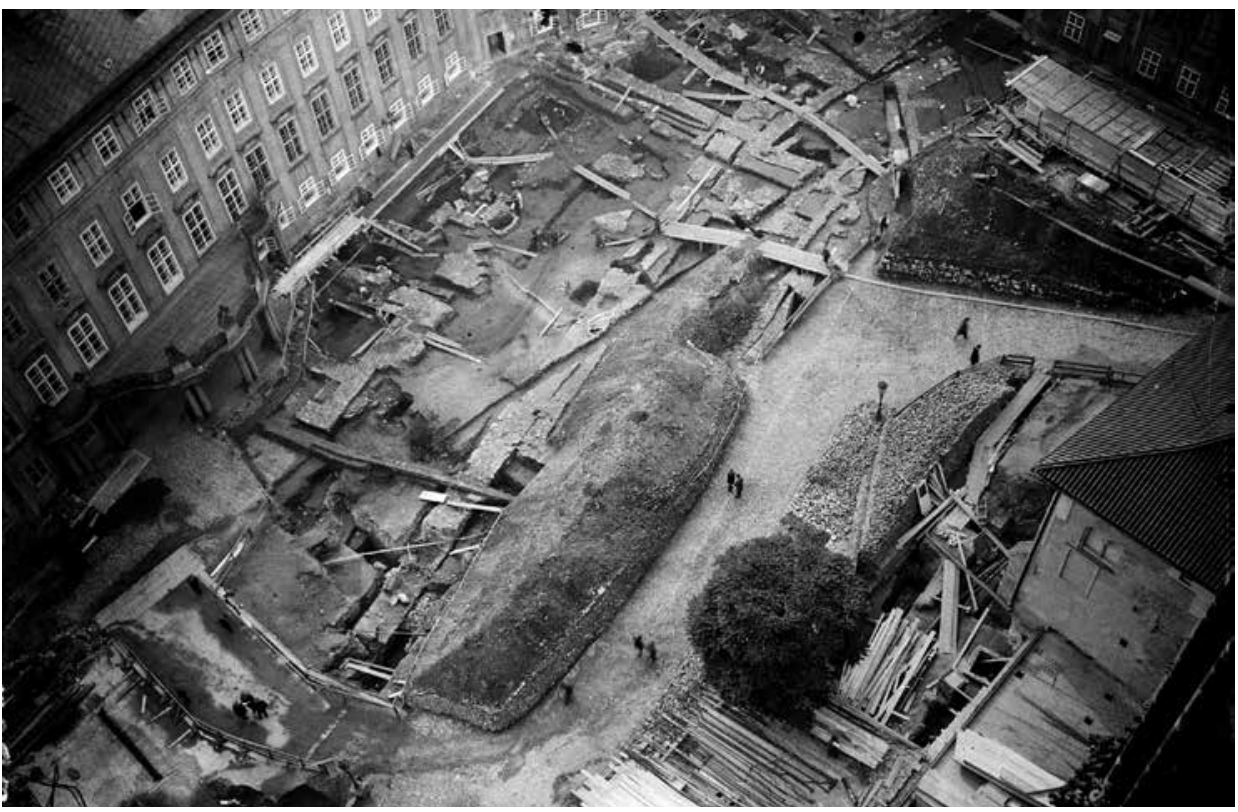

Obr. 4. Pražský hrad, III. nádvoří. Dobový snímek z katedrály sv. Víta z průběhu výzkumu plochy III. nádvoří. ARÚ AV ČR, Praha, FT000103258.

Abb. 4. Prager Burg, III. Burghof. Zeitgenössische Aufnahme des Veitsdoms während der Grabungen im III. Burghof. Archäologisches Institut der Akademie der Wissenschaften der Republik Tschechien, Prag, FT000103258.

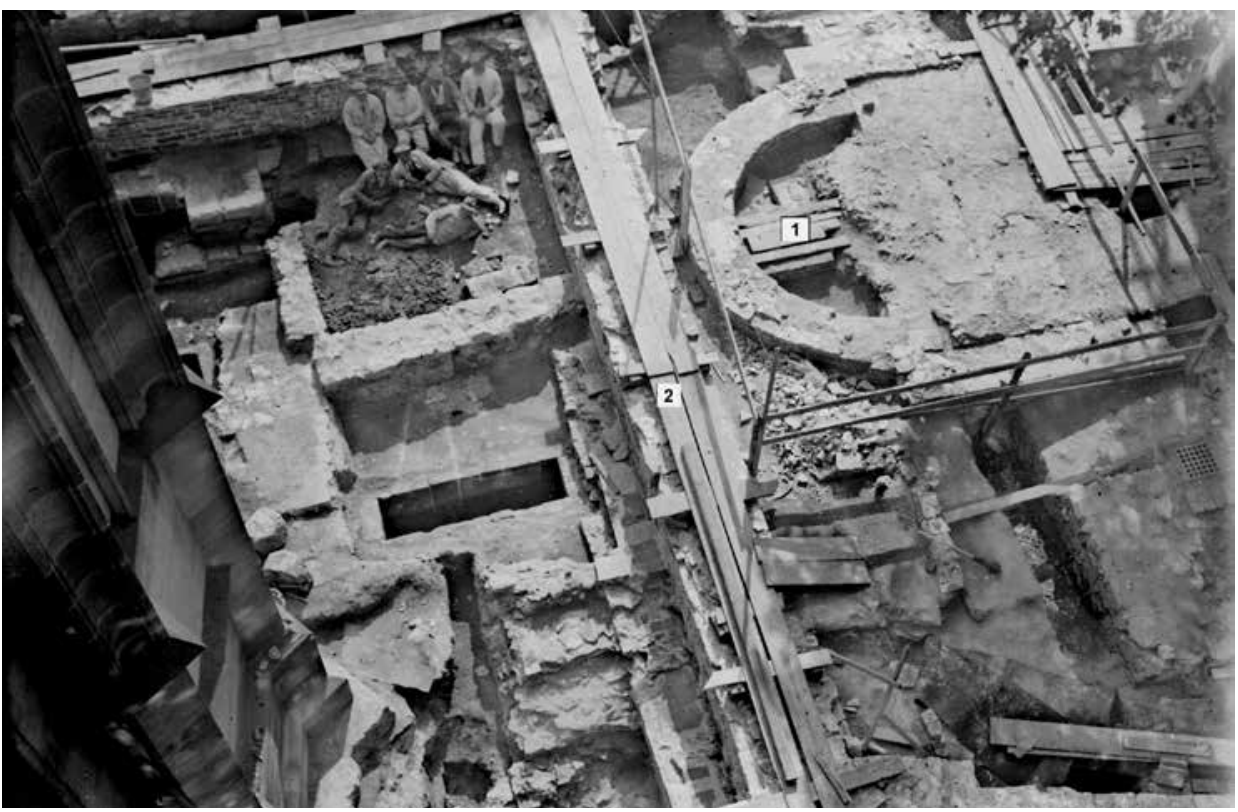

Obr. 5. Pražský hrad, III. nádvoří. Dobový snímek z průběhu výzkumu tzv. rampy, plochy zkoumané při katedrále sv. Víta. 1 - interiér kaple sv. Mořice s podlahovými úpravami, 2 - jižní část transeptu baziliky sv. Víta. Prostor tzv. malých vykopávek. ARÚ AV ČR, Praha, FT000102130.

Abb. 5. Prager Burg, III. Burghof. Zeitgenössische Aufnahme während der Grabungen an der sog. Rampe, der am Veitsdom untersuchten Fläche. 1 - Innenraum der St. Moritzkapelle mit Instandsetzungsarbeiten des Fußbodens, 2 - Südteil des Querschiffs an der Veitsbasilika. Bereich der sog. kleinen Ausgrabungen. Archäologisches Institut der Akademie der Wissenschaften der Republik Tschechien, Prag, FT000102130. 
III. nádvoří. To bylo původně členěno do několika výškových stupňů, které byly odděleny vyzděnými rampami. Dle projektu architekta J. Plečnika ${ }^{1}$ byla plocha nádvoří jako reprezentativního prostoru vyrovnána do jedné úrovně. Vzhledem k výraznému sklonu původního terénu vznikl pod jižní části betonové desky nesoucí dlažbu nádvoří průchozí prostor tzv. velkých vykopávek, v němž mohly být dochovány a zpř́stupněny odkryté archeologické objekty různého typu a charakteru, a to nejen stavby sakrální, profánní, prvky fortifikačního systému, ale i historické terény někdy o mocnosti až několika metrů (obr. 4). ${ }^{2}$ Západně svatováclavské kaple chrámu sv. Víta, kde byly dochovány pozůstatky sakrálních staveb - západní části předrománské svatovítské baziliky a biskupské kaple sv. Mořice (obr. 5), naopak povrch rostlého terénu stoupá již nad úroveň dlažby. Bloky terénu s těmito stavbami, vyvýšené nad nový povrch nádvoří, zůstaly pohledově prrístupné $\mathrm{z}$ plochy III. nádvoří v tzv. malých vykopávkách pod speciálním přístřeškem, opatřeným mříží. Nálezy z ostatních zkoumaných míst nádvoří během výzkumu zanikly, nebo - ve výjimečných př́ípadech, jakým byl nález tzv. bojovníka, některé části roubených staveb, povrchové úpravy terénu a další - byly at' již z prezentačních důvodů či jako objekt možného budoucího zkoumání vyzvednuty $\mathrm{v}$ terénních blocích a přemístěny bud' do expozice nebo do nově vzniklých tzv. velkých vykopávek, či př́ípadně do depozitáře (obr. 1).

Areál byl koncipován jako prŕstupný veřejnosti, a to zejména v jeho východní části, navazující na expoziční prostory starého královského paláce. Ta byla i v druhé polovině 20 . století krátkodobě při prŕležitosti některých výjimečných výstav otevřena běžným návštěvníkům (oblast kostela hypoteticky spojovaného se zasvěcením sv. Bartoloměje a jeho okolí). Prvotní zpřístupnění areálu bylo spojeno s oslavami u př́ležitosti svatováclavského milénia v roce 1929. Této události byl podřízen i definitivní termín ukončení záchranného výzkumu v ploše III. nádvoří.

\subsection{Charakter areálu, jeho technické řešení a další vývoj}

Celková rozloha tzv. velkých vykopávek dosahuje $3000 \mathrm{~m}^{2}$. Původní projekt, vycházející z odkryvu kostela sv. Bartoloměje (?) hradním stavitelem K. Fialou v roce 1920, počítal pouze se zpř́istupněním prostoru $\mathrm{v}$ jeho okolí. Po odkryvu fortifikačního systému v jihozápadní části nádvoří byla původní koncepce přehodnocena. Vzniklý areál je výjimečný nejen rozlohou, ale především svým obsahem a způsobem řešení prezentace celého souboru archeologických

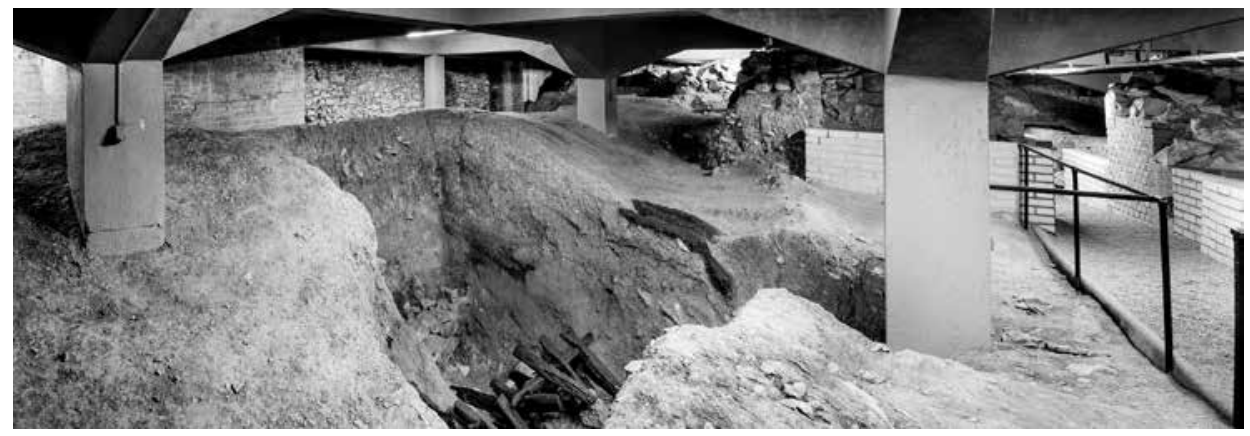

Obr. 6. Pražský hrad, III. nádvoří, západní část. Prezentace vývoje raně středověkého fortifikačního systému - v pozadí (střední část) čelní stěna nejstarší známé hradby Pražského hradu (obr. 2 - hradba A), v popředí dřevěná výztuž komor mladší hradby (obr. 2 hradba B), posunuté více $k$ jihu. Zvlněný povrch terénu odpovídá situaci při budování románské celokamenné hradby (obr. 2 - hradba C) probíhající souběžně s pochozím chodníkem více k jihu (obr. 7). Foto Z. Kačerová, 2014.

Abb. 6. Prager Burg, III. Burghof, Westteil. Präsentation der Entwicklung des frühmittelalterlichen Fortifikationssystems - im Hintergrund (mittlerer Teil) Vorderwand der ältesten bekannten Wehrmauer der Prager Burg (Abb. 2 - Wehrmauer A), im Vordergrund Holzversteifung der jüngeren Wehrmauer (Abb. 2 - Wehrmauer B), etwas nach Süden hin verlagert. Die wellige Geländeoberfläche entspricht der Situation während der Errichtung der ganz aus Stein errichteten romanischen Wehrmauer (Abb. 2 - Wehrmauer C), die parallel zum begehbaren Fußweg weiter südlicher verläuft (Abb. 7). Foto Z. Kačerová, 2014.

1 Detailněji k historii vzniku areálu viz Boháčová 2008, 260-261 s odkazy na starší literaturu. J. Plečnik byl jmenován hradním architektem v r. 1920.

2 Největší mocnosti dosahuje raně středověké sídlištní souvrství v prostoru tzv. jižní rokle, např. při kostele sv. Bartoloměje až ca 400 cm (ca 253-249 m n. m. - v. s. Bpv). 


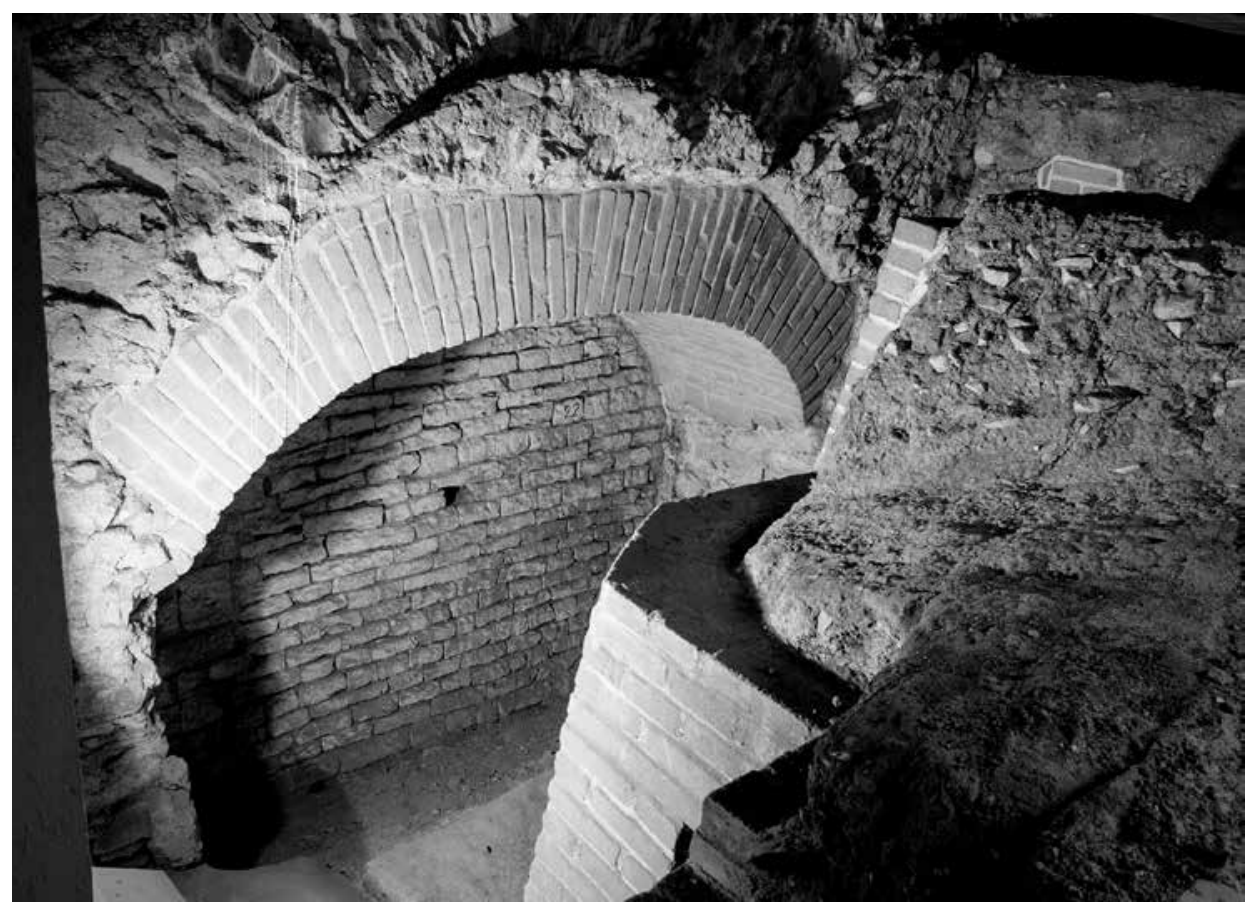

Obr. 7. Pražský hrad, III. nádvoří. Románská hradba (obr. 2 - hradba C), zděná z opukových kvádrủ na maltu. Zachována je př̆i jižním okraji areálu, pohledově je zpř́istupněná systémem průzorů a vydzívek. Průhled mezi obezdívkou vyrovnávacích terénních vrstev a základovým zdivem jižního kř́ídla na obezděný severní líc hradby.

Abb. 7. Prager Burg, III. Burghof. Romanische Wehrmauer (Abb. 2 - Wehrmauer C), Wand aus Handquadern im Mörtelverbund. Sie ist am Südrand des Areals erhalten geblieben und durch ein System von Gucklöchern und Ausmauerungen sichtbar. Durchblick zwischen der Ummauerung der Geländenivellierschichten und dem Fundamentmauerwerk des Südflügels auf die ummauerte Nordflucht der Wehrmauer.

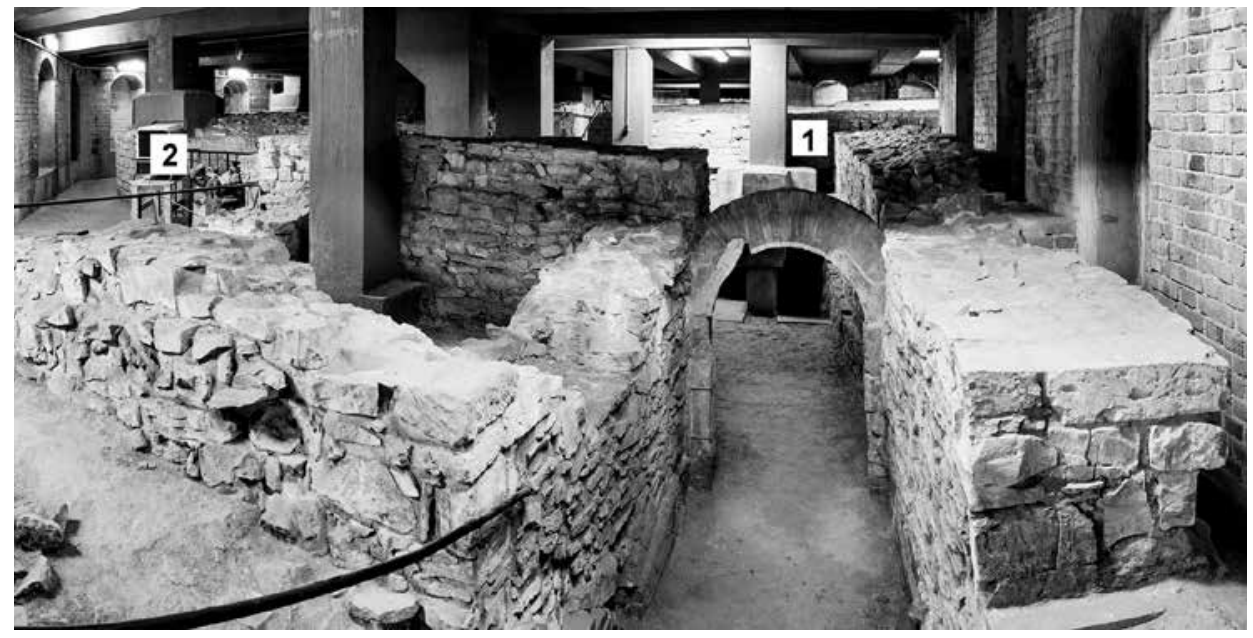

Obr. 8. Pražský hrad, III. nádvoří. Pohled od východu na situaci při východním závěru kostela. 1 - východní zed' románské chodby, 2 - apsida kostela.

Abb. 8. III. Burghof. Blick von Osten auf die Situation am östlichen Kirchenabschluss. 1 - Ostmauer des romanischen Gangs, 2 - Kirchenapsis. 


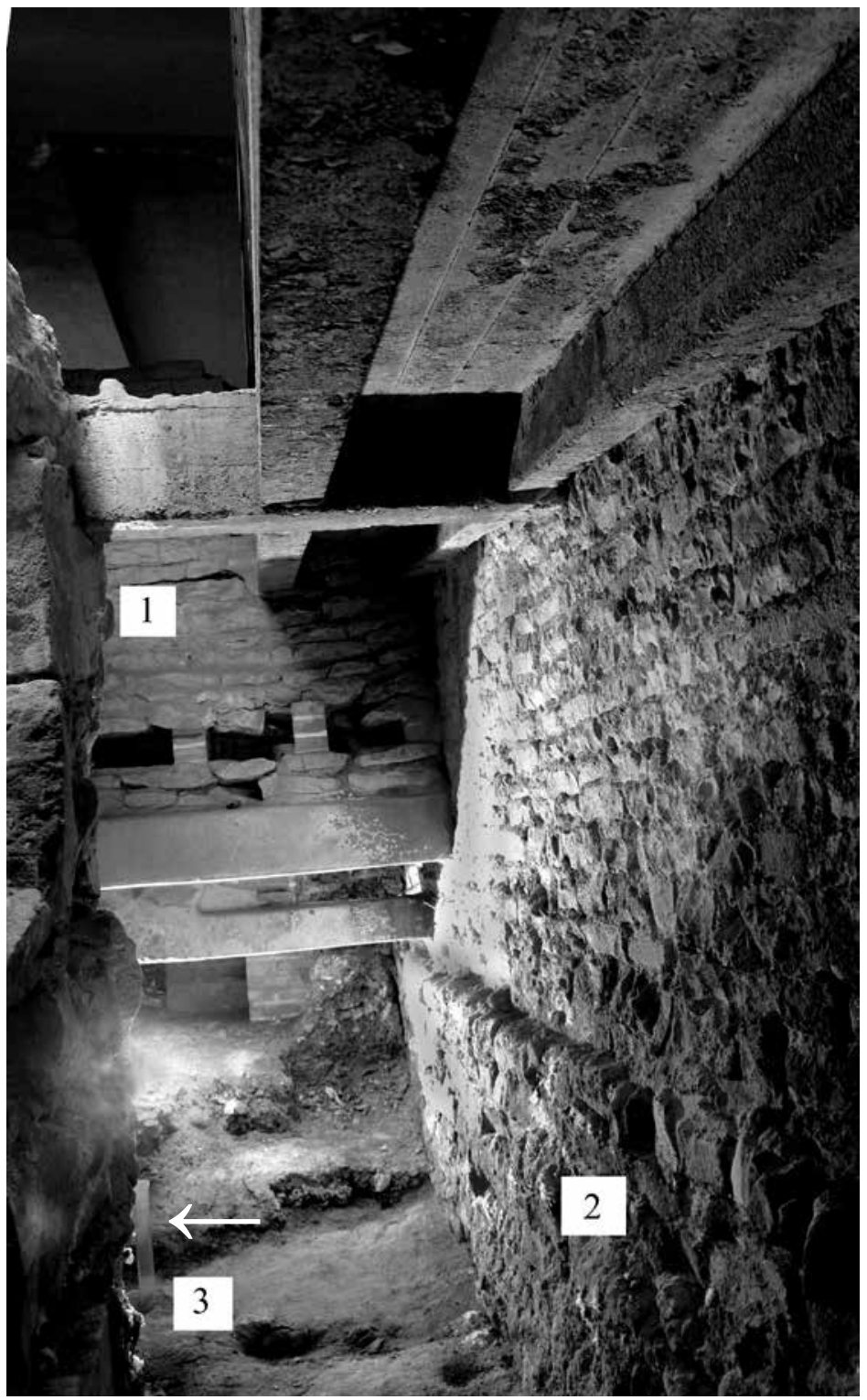

Obr. 9. Pražský hrad, III. nádvoří. Prostor při románské chodbě v pohledu od západu. 1 - báze zdiva západního líce románské chodby nasedající na nosné betonové překlady, 2 - severní obvodové nadzemní i základové zdivo kostela sv. Bartoloměje. V horní části snímku betonová konstrukce prohlídkové trasy, ve spodní pozůstatky kulturního souvrství raného středověku (ca 10. století). V současném povrchu vyznačen prostor písčitého zásypu původní sondy z 20 . let, v níž se v době sanace udržovala stojatá voda. Ke sledování hladiny vody byl zásyp opatřen skleněným válcem (3), umožňujícím sledovat výkyvy její úrovně (označeno šipkou). Se změnou klimatu po rekonstrukci desky III. nádvoří došlo po roce 1998 ke značnému poklesu vlhkosti a voda již do této úrovně nedosahuje. Foto Z. Kačerová, 2014.

Abb. 9. Prager Burg, III. Burghof. Bereich am romanischen Gang in der Ansicht von Westen. 1 - Mauerbasis der auf Betonträgern aufliegenden Westflucht des romanischen Ganges, 2 - nördliches oberirdisches Außen- und Fundamentmauerwerk der St. Bartholomäuskirche. Im oberen Teil der Aufnahme Betonkonstruktion der Besichtigungstrasse, im unteren Teil Überreste der Kulturschichten des frühen Mittelalters (ca. 10. Jhdt.). In der heutigen Oberfläche ausgewiesener Bereich der Sandverfüllung der ursprünglichen Sondiergrabung aus den zwanziger Jahren, in der sich während der Sanierung stehendes Wasser gehalten hat. Zur Beobachtung des Wasserstandes wurde die Verfüllung mit einem Glaszylinder (3) versehen, der die Beobachtung von Pegelschwankungen ermöglichte (mit einem Pfeil gekennzeichnet). Mit der Änderung der klimatischen Bedingungen nach der Rekonstruktion der Betonplatte des III. Burghofs kam es nach 1998 zu einer beträchtlichen Abnahme der Feuchtigkeit, sodass das Wasser diese Höhe nicht mehr erreicht. Foto Z. Kačerová, 2014. 
pramenů. Výzkum zachytil vývoj okrajové části centra Pražského hradu od jeho počátků až po období novověku. Koncepce prezentace si kladla za cíl nejen představit jednotlivé odkryté objekty, ale také postihnout pokud možno vývoj sledované části Pražského hradu v prostorových a chronologických souvislostech (obr. 6). Orientaci v prostoru zajišt’ují průhledy v nosných konstrukcích, které umožňují sledovat situování některých významných objektů, jakými jsou např. celokamenná románská kvádříková hradba či kostel sv. Bartoloměje (?) s přilehlou chodbou (obr. 7-9). Protože výzkum probíhal ve více výškových úrovních a nedosáhl v celé zkoumané ploše povrchu přirozeného terénu, lze ve speciálně $\mathrm{k}$ tomu účelu obezděných průzorech sledovat postupný nárůst stratigrafie, v němž jsou zachytitelné některé významné momenty vývoje - nástup zděné architektury, horizonty dřevěných staveb či úrovně pochozích ploch (obr. 10).

Na rozdíl od tzv. malých vykopávek, kde zůstaly dochovány především základové partie a spodní části nadzemního zdiva kamenné sakrální architektury (obr. 5), a to včetně části typově i chronologicky různých podlahových úrovní a několika hrobů, archeologické památky prezentované v tzv. velkých vykopávkách jsou daleko rozmanitější, jak pokud jde o typy objektů, tak dochované materiály.

Převažujícím materiálem je samozřejmě, jak tomu bývá u většiny archeologických prezentací, kámen (obr. 2:1). Kromě pozůstatků na maltu zděné architektury z pravidelných opukových kvádř́íků i rozmanitého lomového zdiva $\mathrm{v}$ areálu ovšem nacházíme i relikty staveb budovaných na hlínu. Hlína je dalším zde běžně vystupujícím materiálem, nikoliv ovšem pouze jako pojivo či zjílovatělé břidličné podloží, ale i jako součást až několikametrových terénních bloků (obr. 2:3), které uchovávají doklady vývoje této části Pražského hradu od jeho počátků vesměs nejméně po období vrcholného středověku. V jihozápadní části areálu jsou pak dochovány mocné hliněné bloky původní dřevohliněné konstrukce dvou nejstarších fází opevnění jádra přemyslovské rezidence. Díky vysokému podílu jílovité frakce v podloží i v nejstarších částech kulturního nadloží se zde ovšem setkáváme ještě $\mathrm{s}$ jedním naprosto mimořádným fenoménem. Tím jsou prvky dřevěných konstrukcí (Boháčová 2011; obr. 2:2), at' již jde o výztuž hradby (obr. 6), nebo o zcela unikátně dochované pozůstatky dřevěné zástavby (obr. 11), z nichž nejstarší můžeme díky získaným dendrodatům (Dvorská-Boháčová 1999) datovat do druhé třetiny 10. století (obr. 12).

Nad celým areálem byla zkonstruována železobetonová deska (obr. 13), která sloužila současně k položení dlažby na III. nádvoří. Tato deska je nesena soustavou vesměs hluboce založených železobetonových pilírư (obr. 2), pro něž byly hloubeny speciální sondy (dosahující zejména v jihovýchodní části areálu několika metrů). V některých případech byly ovšem pilíre zakládány prrímo na historické zdivo, tedy dnes již neakceptovatelným způsobem. Použití železobetonové konstrukce je jedním z prvých př́ikladů využití této nové konstrukční technologie mimo běžné stavitelství, pro archeologickou rezervaci patrně vůbec poprvé. Její běžné využití v této souvislosti je pak doloženo od 30. let na Vyšehradě. Přirozenou ventilaci v areálu zajištoval především systém otvorů vedoucích do venkovního prostoru. Otvory, umístěné po obvodu nádvoří, bylo možné v klimaticky nepříznivých obdobích roku uzavírat dřevěnými okenicemi. Jejich počet a rozmístění zajištovaly během teplejší části roku dostatečné proudění vzduchu i - jak ukázala měření klimatu před sanací areálu v roce 1997 - optimální stabilitu vlhkosti i teploty (Boháčová 1998). V zimních měsících byly otvory zavírány, čímž se předcházelo promrzání objektů. Tam, kde hrozila pozvolná destrukce stěn terénů, byly bloky obezděny, v některých případech jen vyskládány $\mathrm{z}$ cihel bez maltového pojiva. V některých cihelných obezdívkách byla ponechána volná pole, která byla místy opatřená drátěnými sítěmi, jež měly chránit obnažené stěny terénu před erozí. Do volných prostor areálu byla uložena torza sídlištních situací, vyzvednutých in situ a stabilizovaných ve dřevěných rámech. Později byl areál využit i jako lapidárium. Po odkryvu románského kvádříkového domu na Hradčanském náměstí I. Borkovským v roce 1944 byl do areálu přemístěn i tento objekt, dodnes tak reprodukující v druhotné poloze původní nálezovou situaci.

Počáteční koncepce počítala s průběžnou údržbou areálu. Systematičtěji byla do konce 20. století ošetřována pouze dřeva, a to občasnými nátěry karbolínem, sledovány byly rovněž statické poruchy, projevující se na některých objektech v různých částech areálu. 


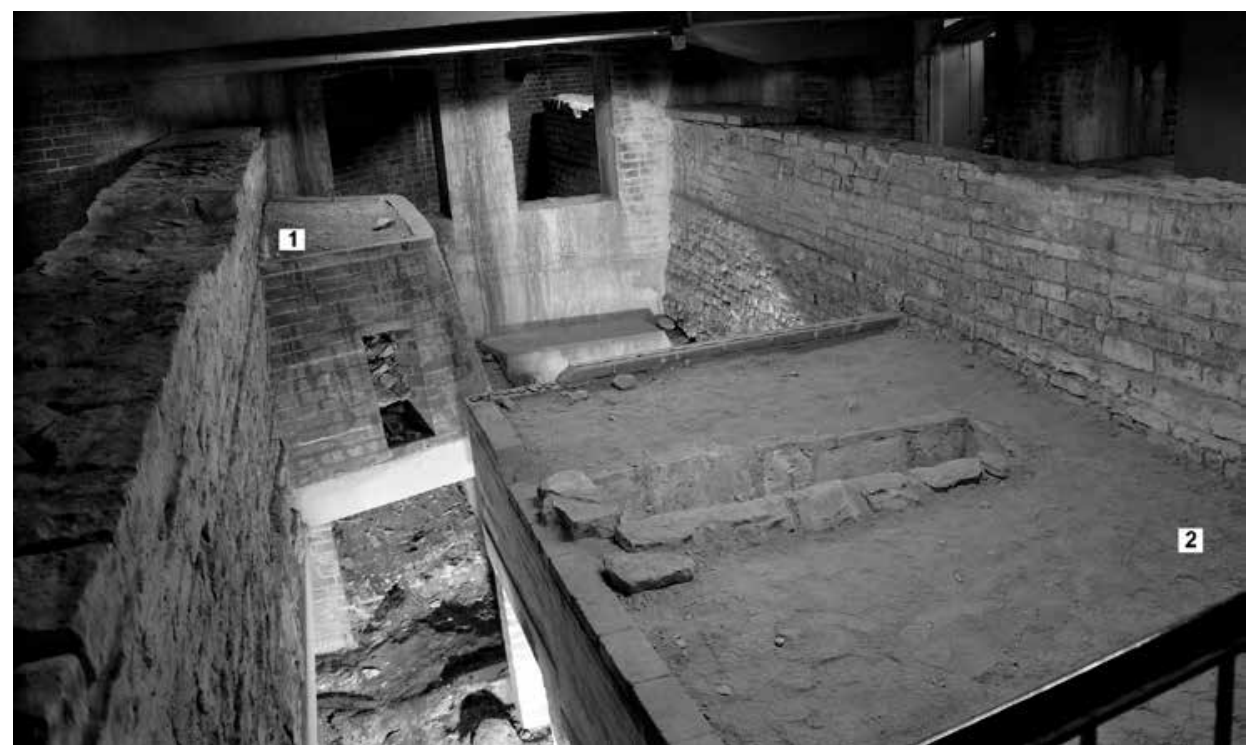

Obr. 10. Pražský hrad, III. nádvoří. Prostor interiéru románské chodby s průhledy na starší terénní situace v pohledu od jihozápadu. $\mathrm{V}$ obezděných blocích terénu zachována původní pochozí úroveň komunikace (1) z doby existence chodby a úroveň báze hrobových jam (2). Ve středu bloku hrobka s opukovým obložením, náležíí muži s kněžskou výbavou (kalich s paténou). Pod obezdívkou vzdálenějšího bloku je možné sledovat proměnu charakteru sídlištních souvrství v rozmezí ca 11. a 12. století. Báze náleží jedné z výjimečně dochovaných dřevěných staveb (podlaha s výpletem - Boháčová 2011). Foto Z. Kačerová, 2014.

Abb. 10. Prager Burg, III. Burghof. Innenraumbereich des romanischen Ganges mit Durchblicken auf die ältere Geländesituation in der Ansicht von Südwesten. In den ummauerten Geländeblöcken erhaltenes ursprüngliches Begehungsniveau der Wege (1) aus der Zeit, als der Gang existierte, und Höhenniveau der Grabgrubenbasen (2). In der Mitte des Blocks mit Steinplatten ausgekleidete Grabstätte eines Mannes mit Beigaben eines Priesters (Kelch mit Patene). Unter der Ummauerung des entfernteren Blocks lässt sich die Veränderung des Charakters der Siedlungsschichten ungefähr für den Zeitraum des 11. und 12. Jahrhunderts beobachten. Die Basis gehört zu einem der außerordentlich gut erhaltenen Holzbauten (Fußboden mit Flechtwerk - Boháčová 2011a). Foto Z. Kačerová, 2014.

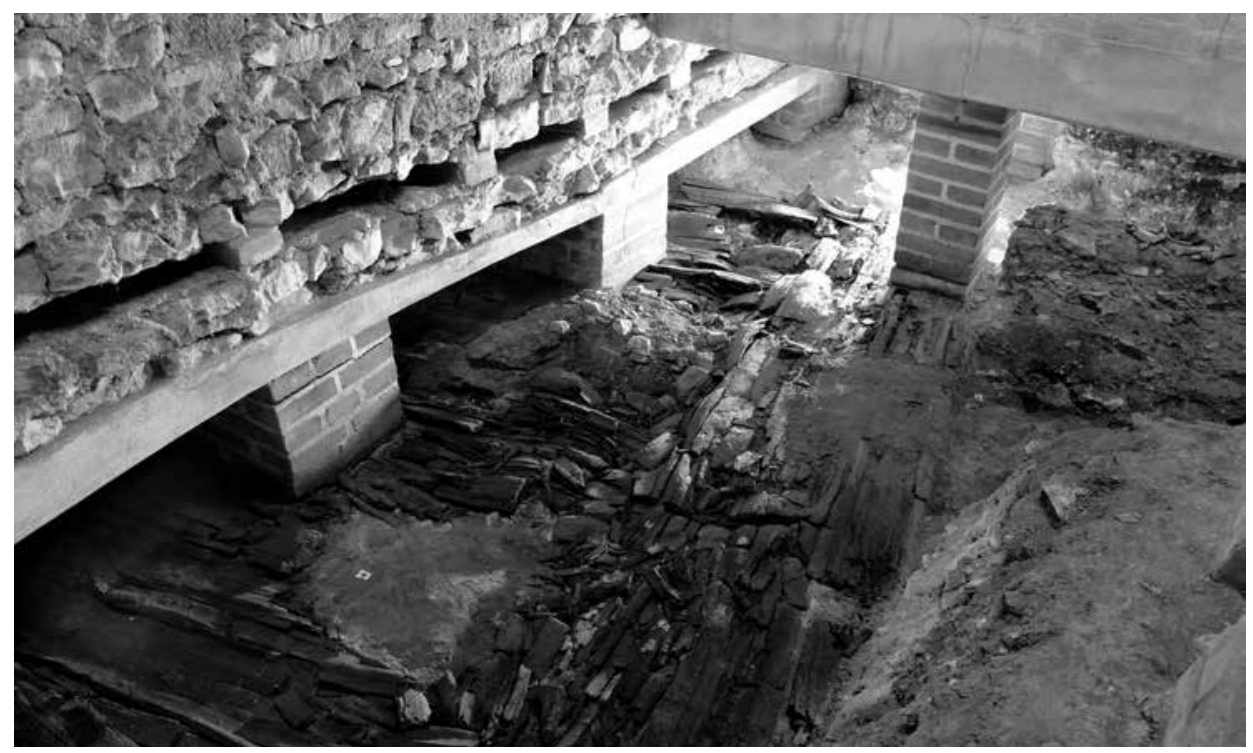

Obr. 11. Pražský hrad, III. nádvoří. Prostor při románské chodbě v pohledu od severu. Torzo dřevěné podlahy (domu?) z mladohradištního období, prezentované pod betonovými překlady. Foto M. Semerád, 2014.

Abb. 11. Prager Burg, III. Burghof. Bereich am romanischen Gang in der Ansicht von Norden. Unter den Betonträgern Torso eines Holzfußbodens (eines Hauses?) aus der Jungburgwallzeit. Foto M. Semerád, 2014. 


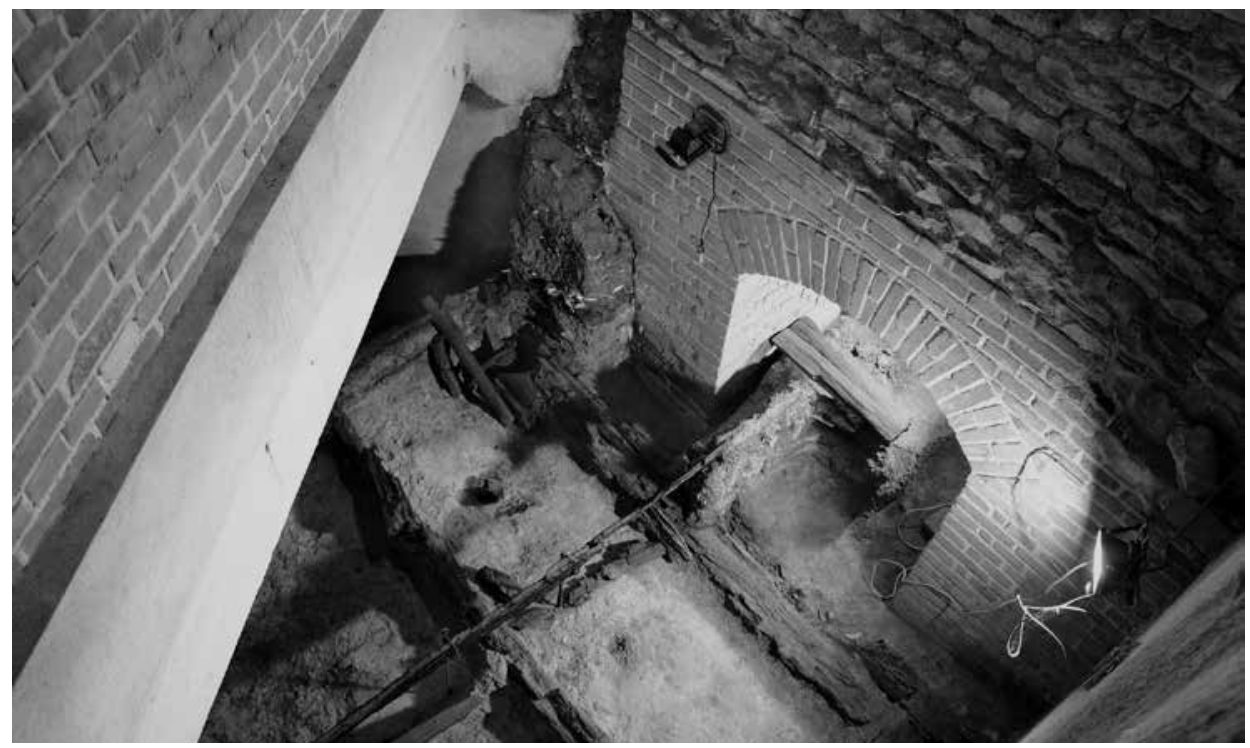

Obr. 12. Pražský hrad, III. nádvoří. Prostor při románské chodbě v pohledu shora od jihu. Vlevo betonová nosná konstrukce se zdivem východní stěny románské chodby, dole centrální část srubové stavby s vertikálními dubovými prvky z 30 . let 10. století. V zadním rohu torzo sídlištního souvrství s dochovaným zánikovým (požárovým?) horizontem stavby a jeho nadložím, dokládajícím nástup mladohradištní keramiky. Foto M. Semerád, 2014.

Abb. 12. Prager Burg, III. Burghof. Bereich am romanischen Gang, Obenansicht von Süden. Links Tragekonstruktion aus Beton mit Gemäuer der Ostwand des romanischen Ganges, unten zentraler Teil eines Blockbaus mit vertikalen Eichenelementen aus den dreiBiger Jahren des 10. Jahrhunderts. In der hinteren Ecke Torso einer Siedlungsschicht mit erhalten gebliebenem Wüstungshorizont (Brandhorizont) eines Baus mit Überschüttung, der aufkommende jungburgwallzeitliche Keramik enthält. Foto M. Semerád, 2014.

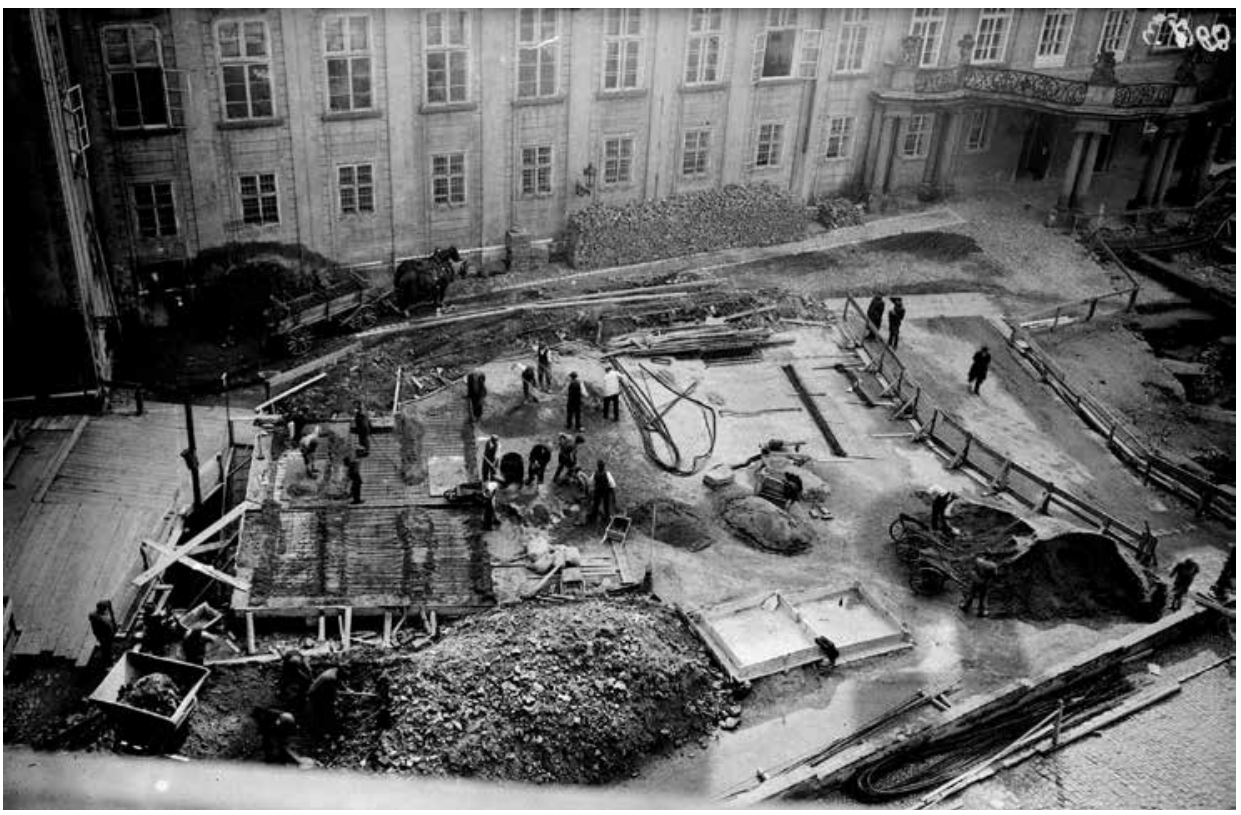

Obr. 13. Pražský hrad, III. nádvoří. Dobový snímek zachycující postup zakrývání areálu železobetonovou deskou. ARÚ AV ČR, Praha, FT000103263.

Abb. 13. Prager Burg, III. Burghof. Zeitgenössische Aufnahme, die den Fortgang der Arbeiten beim Abdecken des Areals mit einer Eisenbetonplatte festhält. Archäologisches Institut der Akademie der Wissenschaften der Republik Tschechien, Prag, FT000103263. 
Areál nebyl v poválečném období dlouhodobě přístupný ani odborné veřejnosti a až do počátku 90. let byl ponechán svému osudu. Byl řadu desetiletí periodicky zaplavován deštovou i puklinovou vodou, průsaky betonu vedly $\mathrm{k}$ vytváření vápenných krust a krápníků na stropě i na archeologických objektech. Vlhkost dosahovala $100 \%$, což ohrožovalo podstatu existence celého areálu. Úroveň spodní vody ve vlhčích obdobích roku dosahovala nejnižších míst areálu (dokumentována na ca 251 m n. m., v. s. Bpv). Část dřevěných prvků podlehla degradaci, nastoupily plísně a na zdivu se objevovaly četné solné výkvěty.

Změnu přinesl příchod nové politické garnitury a s jejím provozem související nutná rekonstrukce nejen dlažby III. nádvoří, ale celé jeho nosné železobetonové konstrukce, nebot' její části byly po téměř sedmdesáti letech provozu zkorodovány. Nezbytná rekonstrukce s sebou přinesla i nutnost drobných zásahů do terénu. Ty vyvolaly nejprve drobné záchranné výzkumy v prvé polovině 90. let, díky nimž bylo získáno základní povědomí o stavu areálu (Boháčová 2009 a průběžné zprávy pro investora, archiv nálezových zpráv ARÚ). Koncem 90. let uspěl pak sanační projekt Archeologického ústavu, podporovaný Kanceláří prezidenta ČR, ve veřejné soutěži Ministerstva kultury ČR (1997-1998; reg. č. KZ97P02OPP006, řešitel I. Boháčová) s koncepcí záchrany a následné dlouhodobé ochrany areálu.

\subsection{Prezentované památky a jejich význam}

Archeologické památky dochované pod III. nádvořím Pražského hradu jsou komplexní prezentací geneze sídelního prostoru při jižním okraji centrálního areálu přemyslovské rezidence především v raném a starším vrcholném středověku. V jižní části lze sledovat vývoj fortifikačního systému a proměny jeho podoby včetně terénních úprav a změn sídlištního

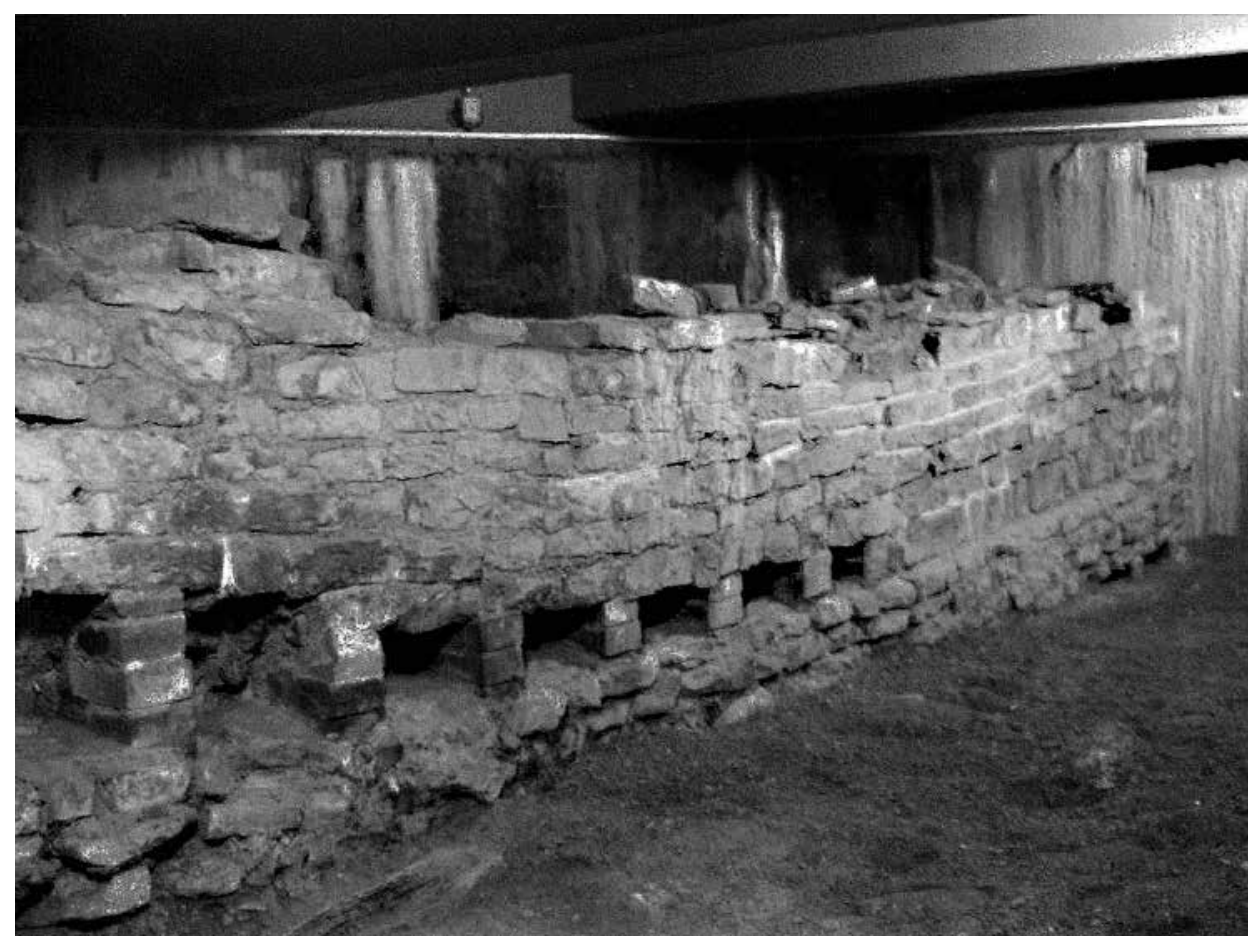

Obr. 14. Pražský hrad, III. nádvoří. Severní část románské chodby spojující baziliku s jednolodním románským kostelem po zásypu povrchu historických terénů pískem. Foto I. Boháčová, 1998.

Abb. 14. Prager Burg, III. Burghof. Die Basilika mit der einschiffigen romanischen Kirche verbindender nördlicher Teil des romanischen Ganges nach Verfüllung der Oberfläche des historischen Geländes mit Sand. Foto I. Boháčová, 1998. 
areálu, v části severozápadní pak nejstarší formy dřevěné zástavby v několika úrovních nad sebou. $\mathrm{Z}$ opevnění je dochována čelní stěna a při západním okraji areálu i pozůstatek tělesa nejstarší známé dřevohliněné hradby (obr. 2:A), z mladší fáze opevnění jsou v rámci několika dílčích sond do hliněného tělesa představeny zejména různé typy dřevěné výztuže hradby (obr. 2:B). Jako nejmladší část a vyvrcholení fortifikačního systému je představena románská hradba (obr. 2:C). Dřevěnou zástavbu reprezentují zejména báze (dvouprostorového?) srubu z přelomu středo- a mladohradištního období a torzo podlahy s výpletem (obr. 11-12).

Profánní architektura mladšího raného středověku a počátku vrcholně středověkého období je zde zastoupena $\mathrm{v}$ několika formách - od kombinované dřevohliněné konstrukce (se zánikovým požárovým horizontem) přes různě dochovaná torza zástavby zděné z pečlivě opracovaných kvádříků (v případě dvouprostorového domu se základy na jílové pojivo) až po dům se zachovanou zděnou šijí, situovaný do bezprostřední blízkosti románského jednolodního kostela (obr. 2). Atypickou konstrukcí románského období je zděná kvádříková chodba, spojující jednolodní románský kostel označovaný hypoteticky za kostel sv. Bartoloměje s bazilikou sv. Víta (obr. 2, 10). V areálu jsou dochovány i další, vesměs mladší zděné stavby či liniové konstrukce z lomového zdiva, spadající dle charakteru materiálu do období vrcholného středověku. Jejich stáŕí však nelze ověřit kvůli ztrátě nálezového kontextu a nebyly ani zatím blíže zhodnoceny. Všechny konstrukce jsou dochovány ve stavu odpovídajícím někdejší nálezové situaci. Dozdívky a další zpevňující prvky jsou užity pouze pro stabilizaci terénu nebo jako nosné konstrukce zdiv. Stratigrafickou vazbu mezi jednotlivými objekty a proměny charakteru uloženin alespoň na vybraných místech zprostředkovávají relikty kulturního souvrství.

V prostoru tzv. malých vykopávek nejsou zachovány historické terény, ale jen zdiva objektů zapuštěných do podloží. Kromě zmíněné biskupské kaple sv. Mořice (v základové partii s jílovým pojivem) byla prezentována jižní část transeptu s hroby i honosnějšími hrobkami a rovněž část západní krypty baziliky (obr. 5). Jako dostupná byla původně koncipována i severní část románské chodby směřující $\mathrm{k}$ bazilice od kostela sv. Mořice a zdiva $\mathrm{v}$ přiléhajícím prostoru (obr. 14).

Mimořádný význam areálu spočívá v několika aspektech, a to jak $\mathrm{z}$ hlediska jeho vědeckého potenciálu, tak z hlediska koncepce památkové péče:

1) v rozsahu, množství i způsobu prezentace památek, 2) v situování polohy areálu, která postihuje vývoj klíčové části centra českého státu, 3) v uchování pramenů pro současný i budoucí výzkum, včetně interdisciplinárního a 4) v možnosti revize a nového zhodnocení již získaných pramenů a archivní dokumentace.

\section{Vyšehrad - areál s bazilikou sv. Vavřince}

\subsection{Souvislosti vzniku}

Areál s bazilikou sv. Vavřince vznikl po cíleném výzkumu a objevu bazilikálního trojlodí (1903, 1924-1926) v místě náhodného nálezu dlaždic při rekonstrukci zázemí kanovnické rezidence (1884) v roce 1934 (Boháčová-Nechvátal 2014). Výzkum ve 20. letech 20. století, který byl součástí rozsáhlé archeologické kampaně vyžádané v souvislosti s př́ípravou regulačního plánu pro Prahu, vedl ke kompletním odkryvu hlavní a jižní lodi baziliky. Severní lod’ baziliky je vkomponována do stávající budovy někdejšího děkanství. Bezprostředně po ukončení výzkumu (1925) došlo k stabilizaci zdiv a zpevnění některých extrémně ohrožených částí betonovými prvky. Od počátku se počítalo s vybudováním zastřešeného objektu nad relikty baziliky, který měl umožnit prezentaci podstatné části jejího půdorysu. Realizaci záměru zkomplikovala tíživá situace počínající hospodářské krize, která razantně zbrzdila finanční dotace na výzkum. Teprve v roce 1932 se podařilo zajistit prostřednictvím Památkového sboruhl.m. Prahy alespoň provizorní dřevěné zastřešení, v roce 1934 pak i železobetonový překryv areálu. Areál byl definitivně upraven pro veřejnost až těsně před vypuknutím druhé světové války (obr. 15, 16; blíže k historii vzniku areálu Boháčová-Nechvátal 2014). 


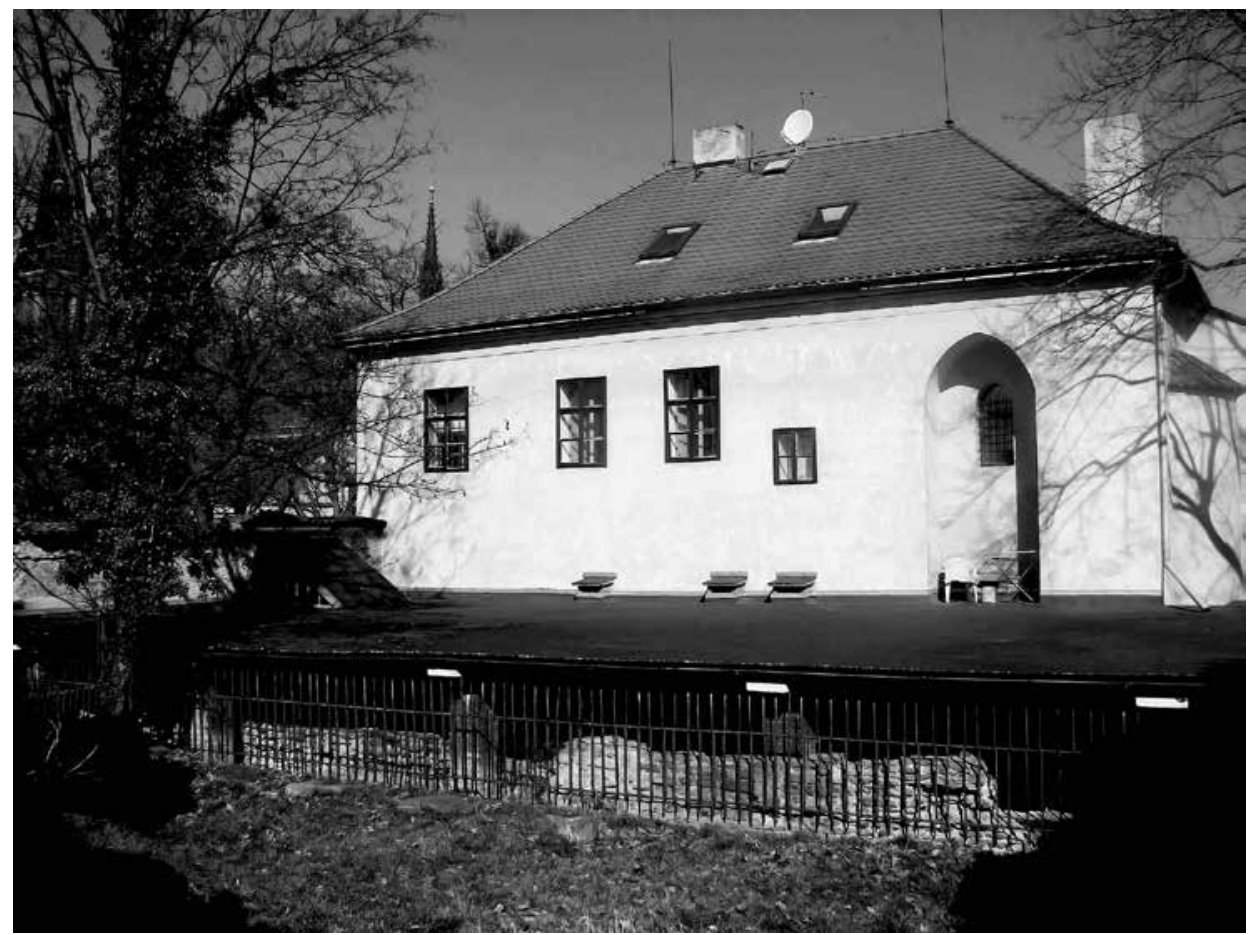

Obr. 15. Praha - Vyšehrad. Pohled od jihu na zastropený areál při budově někdejšího děkanství (čp. 14) z veřejně nepř́istupného přilehlého prostoru. Vpravo patrná apsida severní lodi, dochované ve stávající budově. Foto I. Boháčová, 2014.

Abb. 15. Prag - Vyšehrad. Blick von Süden auf das überdachte Areal am ehemaligen Dekanatsgebäude (Konskriptionsnr. 14) vom angrenzenden, öffentlich nicht zugänglichen Bereich aus gesehen. Rechts ist die im heutigen Gebäude erhalten gebliebene Apsis des Nordschiffs zu sehen. Foto I. Boháčová, 2014.

\subsection{Charakter areálu, technické řešení a jeho další vývoj}

Celková rozloha areálu činní ca $190 \mathrm{~m}^{2}$. V prvotní koncepci řešení byla prezentována dochovaná nadzemní zdiva hlavní a jižní lodi baziliky. Část prostorově limitována ohradní zdí z východu a západu a stávající budovou ze severu byla překryta železobetonovým (pochozím) prŕstř̌š̌kem zakotveným v jižní zdi budovy děkanství a neseným několika cihlovými pilíŕi. Ty byly zakládány do betonového lože, v některých př́ípadech opět na korunu historického zdiva (základové pasy). Tam, kde byl piliř situován v místě původního sloupu baziliky, byla torza základů někdejších patek zafixována betonem v podobě reflektující jejich původní tvar (obr. 16). Prostor s bazilikou byl od exteriéru oddělen kovovou mříží, není tedy tepelně nijak izolován, chráněn je pouze proti deštovým srážkám. Areál byl koncipován jako průchozí. Hlavní vstup byl situován do západního průčelí přibližně do míst původního portálu a osazen byl pseudorománským portálem vytvořeným koncem 19. století (Boháčová-Nechvátal 2014, 8). Tímto vstupem byl umožněn schodištěm přístup přibližně do úrovně někdejší podlahy baziliky - někdejší impozantní podlahy, opatřené původně známými reliéfními dlaždicemi vyšehradského typu. Další vstup byl situován v hlavní lodi a umožňoval průchod k severní apsidě, prostupná do vnějšího prostoru byla i mříž v místech za apsidou jižní lodi. Tím byl zajištěn nejen bezproblémový návštěvnický provoz, ale i dostatečné proudění vzduchu, potřebné pro udržování optimální vlhkosti v areálu. Sondy vyhloubené během výzkumu, a to včetně těch, které odkryly relikty starší předrománské stavby, byly zasypány vykopaným materiálem, přičemž zdiva byla separována dehtovým papírem, zčásti dodnes zachovaným. Tyto zásypy ochránily rovněž torzálně dochova- 


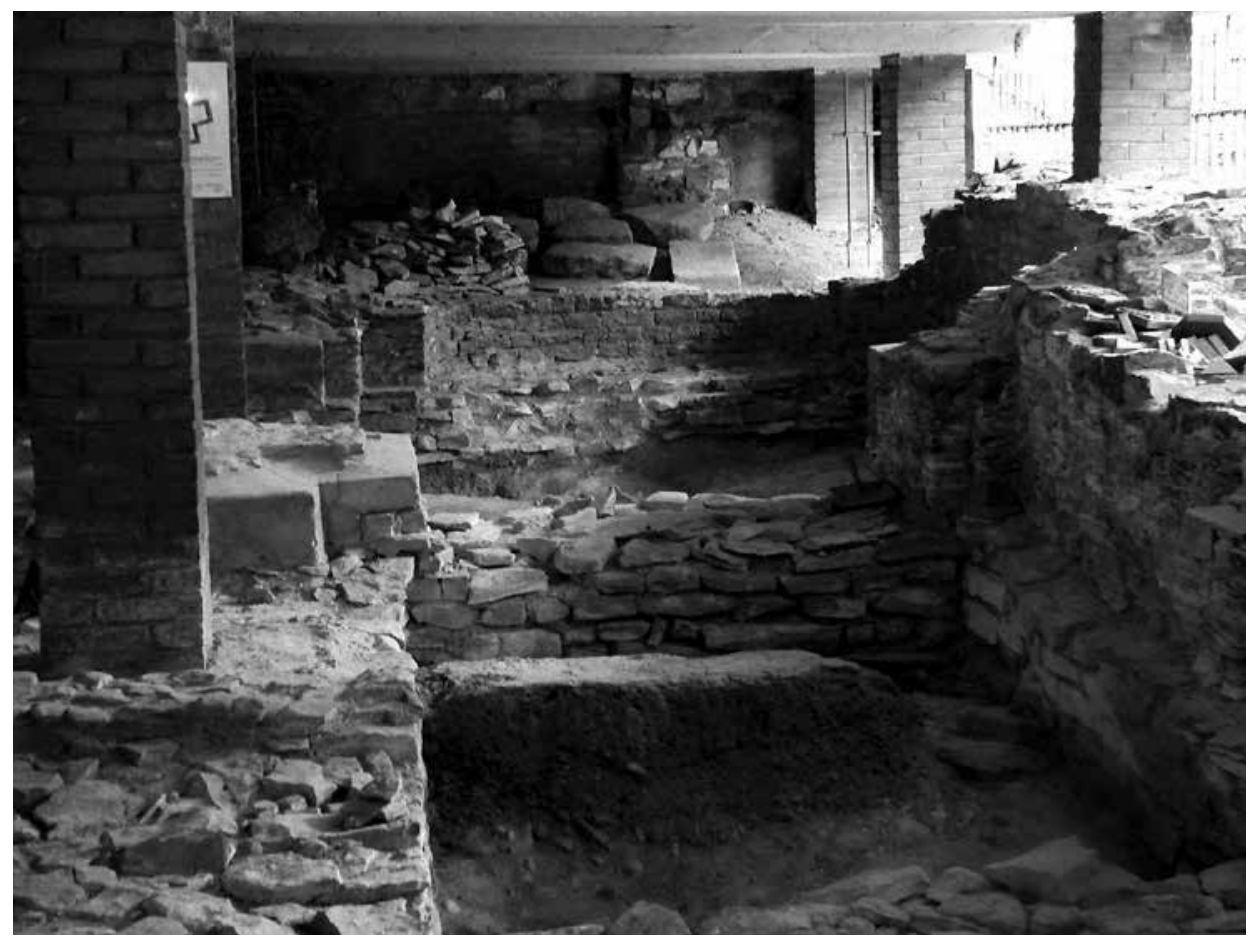

Obr. 16. Praha - Vyšehrad. Pohled do jižní lodi, vlevo patrná úprava základu pro sloup ze 30. let 20. století. Foto I. Boháčová, 2011. Abb. 16. Prag - Vyšehrad. Blick in das Südschiff, links die Herrichtung des Fundaments für einen Pfeiler aus den dreißiger Jahren des 20. Jahrhunderts. Foto I. Boháčová, 2011.

né kulturní souvrství, rozsah zásahů do něj však nebyl zpětně bez ověření v terénu zcela přesně rekonstruovatelný. Po další etapě archeologického výzkumu zaměřené na ověření situace dlažby a předchozími etapami odkrytého staršího zdiva neznámé stavby (bez dochované dokumentace), kterou vedl v letech 1968-1970 B. Nechvátal, byla snížena úroveň terénu a areál byl vybaven dřevěnou lávkou pro návštěvníky. Nově byly prezentovány i části základového zdiva baziliky včetně mezilodních pasů. Zdivo starší stavby, interpretované tehdy poprvé jako předrománská stavba sakrální (Kašička-Nechvátal 1976), zůstalo taktéž odkryté, jeho prezentace však nebyla nijak návštěvnicky atraktivní, nebot' jeho průběh byl z podstatné části dřevěnou lávkou překryt. Do areálu byly umístěny náhrobní kameny z přilehlého prostoru pohřebiště.

$\mathrm{V}$ následných letech nebyla údržbě areálu věnována žádná pozornost. Byl průběžně i když jen př́íležitostně - př́stupný, a to aniž byla stanovena základní pravidla návštěvnického režimu. Postupně tak došlo k jeho značné degradaci, na některých místech i k rozvolnění koruny i líce zdiv, k poškození části zdiva předrománské stavby, destrukci terénních reliktů i některých stabilizačních prvků. Tento stav vedl k formulaci projektu jeho sanace zajištovaného Archeologickým ústavem AV ČR, Praha, v. v. i,, podpořeného Pražským archeologickým fondem a prostřednictvím Královské kolegiátní kapituly sv. Petra a Pavla na Vyšehradě jako správce objektu ze značné části i Magistrátem hl.m. Prahy.

\subsection{Prezentované památky a jejich význam}

Přestože prvotním záměrem byla prezentace pouze jediné, i když z hlediska kulturně-historického výjimečné památky, je význam areálu mimořádný. V centrálním prostoru barokní pevnosti, upraveném v dobovém duchu přelomu 19. a 20. století na památník české svébytnos- 
ti a státnosti, bylo vyčleněno místo přirozeně izolované od okolního prostředí pro prezentaci archeologického nálezu a jeho kontextu. Vnímavému návštěvníkovi tak byl umožněn - $\mathrm{s}$ určitou nadsázkou řečeno - vstup do doby vrcholné slávy raně středověkého Vyšehradu, rozhodně však prŕmý osobní kontakt s jednou z nejstarších i intaktně (alespoň pokud jde o půdorys) dochovaných sakrálních staveb v Čechách. Citlivé řešení ochrany obnažených zdiv baziliky společně s př́mým vizuálním propojením areálu s bezprostředním okolím umožňuje dodnes vnímat širší kontext stavby, situované $\mathrm{v}$ jedné $\mathrm{z}$ dominantních poloh při rozhraní vnitřního areálu vyšehradské akropole a přiléhajícího předhradí. Relikty starších situací, včetně neznámé stavby z doby starší než bazilika, kladená do 70 . let 11. století (např. Varadzin 2009, 311), zůstaly dochovány pro možný budoucí výzkum. Význam tohoto areálu spočívá v obdobných aspektech jako v př́ípadě areálu pod III. nádvořím, tj. 1) v uchování významné sakrální architektury, náležící k nejstarším památkám Čech, 2) v situování polohy areálu v centru prvořadé lokality českého státu, 3) v uchování pramenů pro současný i budoucí výzkum, včetně interdisciplinárního a 4) v možnosti revize a nového zhodnocení již získaných pramenů a archivní dokumentace.

\section{Projekty sanace areálů a jejich výsledky}

Areály pod III. nádvořím Pražského hradu i areál s bazilikou sv. Vavřince jsou dnes součástí vyhlášených národních kulturních památek - NKP č. 1 - Pražský hrad a NKP Vyšehrad. Oba prošly před několika lety rozsáhlou sanací, a to v obou prŕípadech nikoliv z iniciativy jejich vlastníka, resp. správce, ale z iniciativy Archeologického ústavu AV ČR, Praha, v. v. i. Ačkoliv rozsah sanace nelze vzhledem $\mathrm{k}$ rozsahu areálů a jejich odlišnému charakteru srovnávat, základní koncepce byla $\mathrm{v}$ obou případech shodná - východiskem byl revizní výzkum (v případě

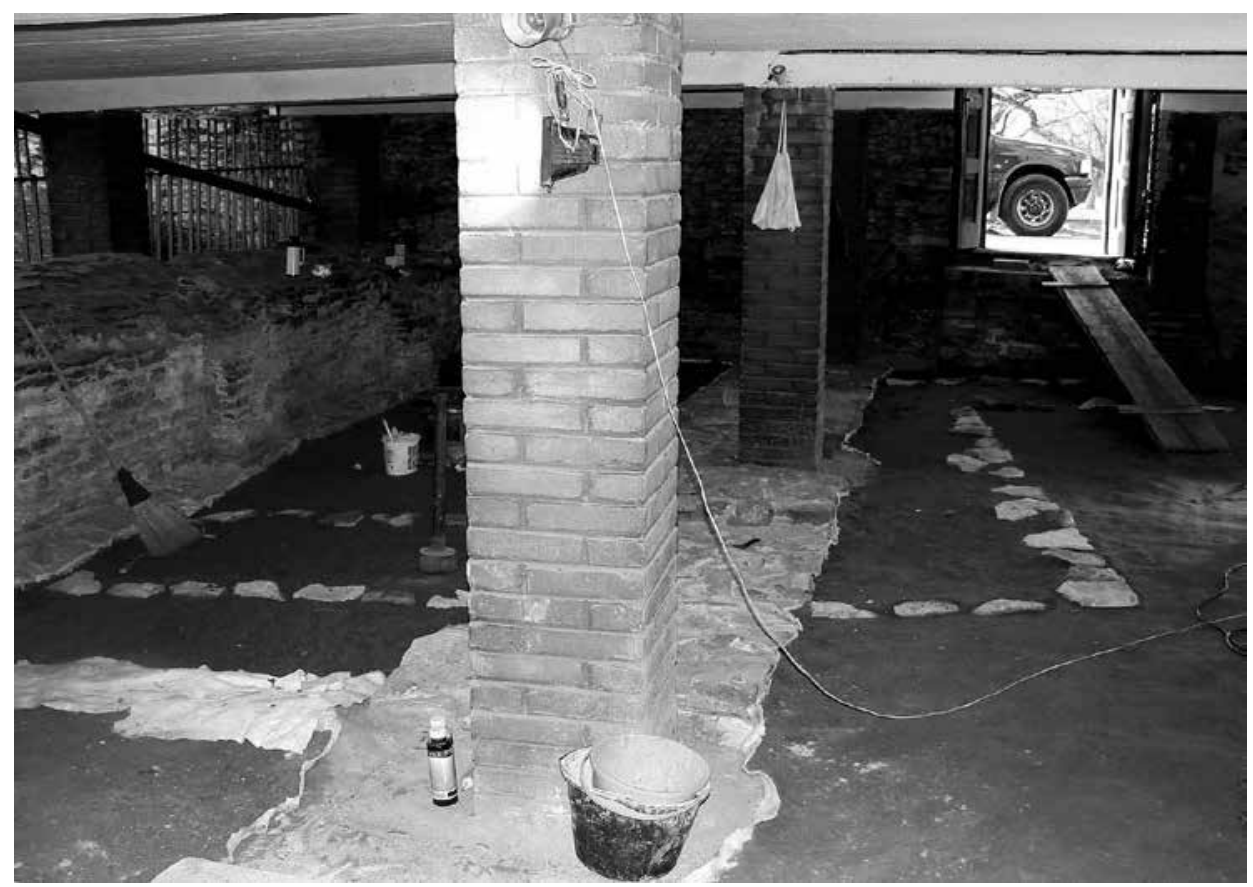

Obr. 17. Praha - Vyšehrad. Pohled ze stř̌ední části hlavní lodi k jihozápadu. Stav po zasypání podloží zhruba do výše rozhraní základového a nadzemního zdiva se stylizovanou rekonstrukcí prủběhu jihozápadní části zdiva předrománské stavby. Foto J. Mjartan, 2011.

Abb. 17. Prag - Vyšehrad. Blick vom Mittelteil des Hauptschiffs in Richtung Südwest. Zustand nach Verfüllung des Untergrunds auf die ungefähre Höhe der Grenze zwischen Fundament und oberirdischem Gemäuer mit stilisierter Rekonstruktion des Verlaufs des südwestlichen Mauerwerksteils eines vorromanischen Baus. Foto J. Mjartan, 2011. 
Pražského hradu klíčových situací, v př́ípadě Vyšehradu komplexní) a dokumentace veškerých objektů a obnažených řezů terény, detailní průzkum dostupných materiálů a komisionální rozhodování a posuzování navržených postupů rozsahu sanace a konzervačních prací. Zatímco pod III. nádvořím byly řezy terény pouze začištěny, $\mathrm{v}$ areálu s bazilikou sv. Vavřince došlo $\mathrm{k}$ znovu odtěžení veškerých novodobých zásypů archeologických sond. V areálu III. nádvoří byly některé snížené polohy, u nichž hrozila eroze stěn, zasypány pískem po zakrytí geotextilií (obr. 9, 14), případně stabilizovány cihelnou obezdívkou bez maltového pojiva. Na Vyšehradě nahradil písčitý zásyp původní zásypy překopanou zeminou, a to až do úrovně základového ústupku tak, aby zdivo bylo v maximální míře ochráněno před výkyvy vlhkosti a teploty (obr. 17). Na Hradě byly pochozí terény překryty geotextilií a vysypány štěrčíkem a byla tak zajištěna ochrana jejich povrchu před mechanickým poškozením. Na Vyšehradě byl povrch písku pouze zhutněn a navržena (dosud nerealizovaná) rekonstrukce lávky, která má umožnit návštěvníkům pohyb areálem tak, aby nebyly ohroženy archeologické nálezy. Zcela zasypáno bylo nezpevněné zdivo předrománské stavby, budované na jílovité pojivo, které bylo ohroženo vysycháním. Prezentace stavby byla autorkou projektu sanace navržena pouze v náznaku, a to formou mírně zapuštěných opukových kamenů do písčitého lože, reflektujících líce původního zdiva (obr. 17). ${ }^{3}$ Při apsidě jižní lodi byla do míst rámcově odpovídajících původnímu místu nálezu položena na ploše zhruba dvou metrů čtverečních replika dlažby vyšehradského typu (Boháčová 2013). Definitivní úprava areálu vyžaduje komplexní profesionální řešení, které je plně v gesci vlastníka areálu, tj. Vyšehradské kapituly.

Maximální pozornost byla věnována $\mathrm{v}$ obou prrípadech sanace kompletaci původní terénní dokumentace. Pro areál III. nádvoří byl sestaven Průvodce archeologickými prameny (Boháčová 1998, I-IX s obr. přílohou), v němž byla shromážděna a opatřena popisky dostupná plánová dokumentace jak z Archivu Pražského hradu, tak z hradního detašovaného pracoviště pražského Archeologického ústavu. Byla provedena identifikace řezů i některých objektů. Jednotlivá pare Průvodce byla umístěna v Archivu Pražského hradu, na hradním pracovišti ARÚ a v archivu nálezových zpráv ARÚ. Vyhotovena byla i kopie prvopisů terénních deníků z let 1925-1929 a popsány některé fotografie. $V$ případě Vyšehradu byla situace usnadněna díky nedávno ukončenému projektu B. Nechvátala a jeho publikačnímu výstupu (Nechvátal 2009), v němž byla starší dokumentace zpř́ístupněna. Archivní studium se tak mohlo omezit především na prameny týkající se historie vlastního areálu (Boháčová-Nechvátal 2014).

Součástí přípravné fáze projektů sanace byla $\mathrm{v}$ obou případech vedle průzkumu konstrukcí, materiálů i klimatu aplikace dř́ve nerealizovaných analýz. Ty v případě Pražského hradu zahrnovaly širokou škálu typů a materiálů (dendrochronologie, archeobiologie, geoarcheologie aj.) a dlouhodobé sledování klimatu, v př́ípadě Vyšehradu šlo již jen o některé doplňující analýzy, nerealizované předchozím badatelským projektem. Podstatou návrhu řešení rekonzervace byla $\mathrm{v}$ obou případech minimalizace veškerých rekonzervačních zásahů, důraz na mechanickou ochranu konstrukcí a terénů, využití tradičních technologií, trvalý monitoring klimatu, komisionální posouzení návrhu řešení, návrh periodických kontrol stavu materiálů a prostředí a návrh návštěvnického režimu. Veškeré průvodní informace a dokumentaci k realizovaným projektům obsahují př́íslušné výzkumné zprávy (Boháčová 1998; 2011a).

Lze konstatovat, že oba areály byly zbudovány s využitím nejmodernějších stavebních technologií a s maximálním respektem $\mathrm{k}$ památkám a $\mathrm{k}$ jejich výpovědní hodnotě (s výjimkou výše zmíněných konstrukcí zakládaných přímo na historické zdivo). Sama podstata areálů byla v minulosti ohrožena především absencí pravidelné, zcela detailní a profesionální kontroly archeologických památek, a tedy údržby a preventivní ochrany památek i prostředí, v němž jsou prezentovány. V prŕípadě Pražského hradu je z archivních materiálů ovšem zřejmé, že jak v době vzniku areálu, tak zejména ještě ve válečných letech byl stav areálu monitorován a vzniklé problémy řešeny. Za rizikový faktor byl od počátku považován diskutabilní rozsah zastropení

3 Záměr prezentace průběhu zdiv všech odkrytých částí půdorysu předrománské stavby v interiéru baziliky byl aktuálně zmařen zcela nevhodným, i když provizorním (2011-dosud) umístěním pochozí lávky nad západní část předrománské stavby. 


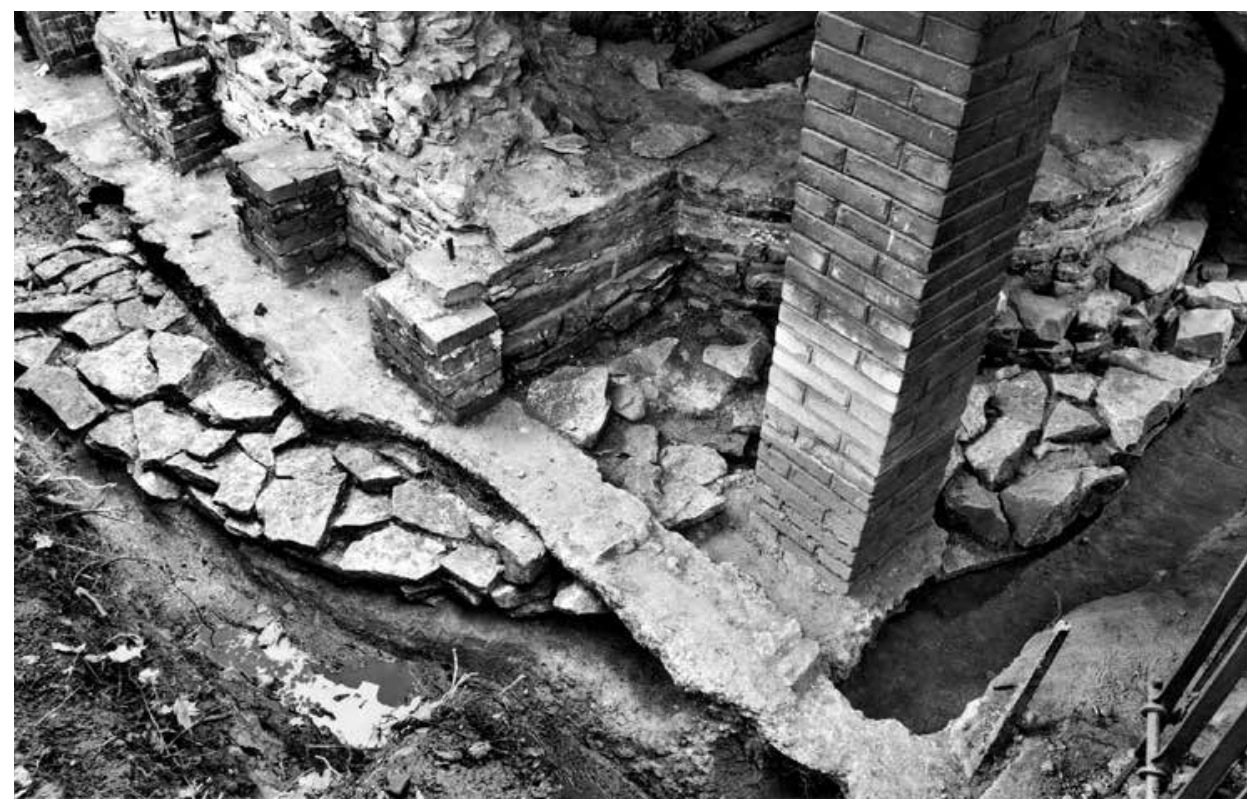

Obr. 18. Praha - Vyšehrad. Oblouk apsidy centrální stavby pod jižní apsidou baziliky. Foto J. Lebeda, 2011.

Abb. 18. Prag - Vyšehrad. Rundbogen der Apsis des Zentralbaus unter der Südapsis der Basilika. Foto J. Lebeda, 2011.

prostoru s archeologickými památkami a jeho izolační schopnosti z hlediska kolísání klimatu v areálu, zejména však vzhledem k průnikům vody. Byly vedeny diskuse o technologii izolace dlažby III. nádvoří a hledány cesty k zabezpečení dostatečné regulace teploty a vlhkosti (další větrací otvory uzavíratelné v zimním období, klimatizace). Problémy s pronikáním vody, vznikem vápenatých výluhů i výskytem solí se objevovaly již od závěru 20. let. V řadě archivních dokumentů z období let 1927-1946 lze nalézt doklady o kontrolách stavu areálu, nedokončených pracích na zastř̌ešení „,vykopávek“ při katedrále i doklady o expertízách ověřujících původ vody prosakující do areálu (puklinová, povrchová i splašková) či nezávadnost vzácných hub vázaných na specifické prostředí areálu (APH, fond Stavební správa II/17-2, č. i. 336 a 338; např. ss1147/1928, ss163/32, ss19/40 z 8. 1. 1940, ss661/41 z 22. 5. 1941, ss1174/42 z 19. 11. 42). Maximální stabilita prostředí, teploty a zejména vlhkosti je zásadním problémem i v případě areálu s bazilikou sv. Vavřince na Vyšehradě. Teplotu areálu, který je vůči okolnímu prostředí zcela z jižní strany otevřen, regulovat samozřejmě nelze, intenzitu proudění vzduchu podporuje stabilně otevřený průduch k severu. Základním požadavkem je tak ochrana areálu vủči pronikání nadbytečné vlhkosti. Stabilitu vlhkosti zajištovalo jednak zastropení s př́islušným odvodem deštové vody mimo areál, jednak původní zasypání obnažených konstrukcí až do úrovně rozhraní základového a nadzemního zdiva, které bylo během sanace v roce 2011 obnoveno.

Součástí projektů bylo i navržení informačního systému pro návštěvníky areálů. Realizace těchto návrhů je $\mathrm{v}$ obou případech závislá na správcích areálů. V př́ípadě Pražského hradu nebyl informační systém realizován, mj. patrně i z důvodu minimálního návštěvnického provozu. Na Vyšehradě by měl být součástí budoucího informačního systému v rámci celé NKP.

Kromě zastavení degradace konstrukcí a terénů a pořízení nové dokumentace přinesly projekty sanace $\mathrm{v}$ obou případech zcela výjimečné poznatky, at' již získané prostřednictvím dříve nerealizovaných analýz, nebo při záchranném výzkumu vyvolaném sanačními pracemi.

V př́ípadě Pražského hradu lze zmínit informace podstatné pro detailní rekonstrukci georeliéfu příslušné části hradčanského ostrohu, pro rekonstrukci geneze fortifikačního systému nebo poznatky umožňující vyhodnocení dřevěné zástavby v jižní části Hradu či rekonstrukci 
životního prostředí, potravinové skladby a využívání dřeva v raném středověku jako suroviny. Byla vytvořena i databanka maltových pojiv, deponovaná pro budoucí výzkum na odboru památkové péče Kanceláře prezidenta. Za výjimečný pramen s obecným využitím lze považovat zcela unikátní (jak počtem, tak stavem dochování) soubor dochovaných dřevěných prvků, který se stal základem pro dendrochronologickou analýzu a vytvoření dubového standardu pro český raný stř̌edověk. Mimořádný význam areálu a nově získaných pramenů z areálu III. nádvoří Pražského hradu pro další výzkum, včetně interdisciplinárního studia prostředí i objektů byl již zhodnocen a většina nově získaných výsledků byla postupně publikována (Boháčová 1998; 1999; 2001; 2011; Dvorská-Boháčová 1999; Čulíková 1998; Kozáková-Boháčová 2008).

V př́ípadě Vyšehradu se nenaplnila očekávání, pokud jde o možnou revizi nálezové situace dlažby vyšehradského typu a rozsah dochování terénů z doby před zbudováním baziliky. Ty jsou dochovány jen $\mathrm{v}$ nepatrném torzu, na jehož povrchu, nasedajícím přímo na původní terén tvořený pozůstatky jedné z vltavských teras, lze rozeznat stopy lidských aktivit (Kuneš 2012). Výsledky revizního výzkumu zaměřeného na ověření stáří a půdorysu předrománské stavby však přinesly zcela nečekaný objev v podobě zalomení známého zdiva směrem $\mathrm{k}$ jihu a jeho navázání na dříve nepředpokládanou, i když v minulosti již odkrytou jižní apsidu (obr. 18; srov. Boháčová-Nechvátal 2014, obr. 9) monumentální stavby centrálního typu, jejíž minimální východozápadní rozměr byl již v průběhu projektu sanace odhadnut na 25 metrů. I areál s bazilikou sv. Vavřince tak poskytl současné archeologii mimořádně cenné prameny přesahující rámec jedné konkrétní - i když pro počátky českého státu prvořadé - lokality, $\mathrm{v}$ tomto př́padě pro studium nejstarší vrstvy české sakrální architektury. Stavba, jejíž rozměry i půdorysný typ byly definitivně potvrzeny následným badatelským terénním výzkumem (L. Varadzin, ARÚ Praha, 2014) vně vlastního areálu - tedy již mimo dané téma př́spěvku, je pro daný dobový kontext a české prostředí zcela bez analogií.

\section{Závěr}

Př́klady prezentací archeologických památek in situ z Pražského hradu a Vyšehradu, tedy z prostoru prvořadých kulturně-historických památek České republiky, chráněných statutem NKP, ukazují, že vznik těchto prezentací má zcela mimořádný význam z mnoha hledisek:

1) ochrana nemovitého kulturního dědictví - uchovávají nemovité památky výjimečné kulturní a historické hodnoty;

2) historie památkové péče obecně - uchovávají historické doklady péče o kulturní dědictví a jejího vývoje;

3) hospodaření s archeologickými prameny - umožňují uchovat jinak nenahraditelné prameny pro budoucí výzkum i pro využití nových metod a výzkumných technologií;

4) vědecké vyhodnocení archeologických pramenů - umožňují ověření starších poznatků a jejich revizi i jejich propojení s širším nálezovým kontextem;

5) působení na širokou veřejnost - umožňují bezprostřední kontakt široké veřejnosti s jinak nedostupnými - protože archeologizovanými nebo zaniklými - autentickými doklady minulosti.

Z uvedených př́kladů je dobře patrné, že podstata prezentací archeologických památek in situ netkví ani tak v kvalitě záměru a projektu prezentace, ale spočívá především v její udržitelnosti, tedy v zabezpečení pravidelné i preventivní péče o dochované památky, soustavném monitoringu změn klimatu a materiálů a předcházení degradace památek, a to nejen ve výhledu generace „výkopců“ památky, tvůrců projektu či jeho realizace, ale v čase longue durée. Nejde ovšem jen o otázku finančního zabezpečení a příslušné profesionální odbornosti, ale i o otázku možné kontinuální zodpovědnosti vlastníka či správce památky. Je zřejmé, že garantem kontinuity a optimálních řešení nemusí být ani státní či jiná veřejná instituce, nebot' i její rozhodování o již existující památce a její budoucnosti může být kdykoliv ovlivněno vnějšími - at' již ekonomickými či politickými - vlivy a událostmi. Často pak může osud památky záviset na iniciativě a invenci jednotlivce a jeho subjektivních hodnotových měřítkách. Řešením, které může zajistit 
v dlouhodobém výhledu udržitelnost zachování archeologických památek in situ, ${ }^{4}$ je tak v současné době pouze vyhlášení prezentovaných památek za kulturní památky či za archeologickou památkovou rezervaci, a to za jasně stanovených podmínek garantujících jejich pravidelnou detailní a profesionální kontrolu a údržbu.

Př́íspěvek byl zpracován v rámci projektu MK ČR reg. č. 13P01OVV014.

\section{Literatura}

BOHÁČOVÁ, I., 1998: Archeologický areál III. nádvoří Pražského hradu. Průvodce problematikou a archeologickými prameny, 1-9, výzkumná zpráva k projektu MK ČR ev. č. KZ97P02OPP006, ulož. v archivu ARÚ AV ČR, čj. 6540/98.

- 1999: Archeologický areál pod III. nádvořím Pražského hradu. Poznámky k jeho významu a vypovídací hodnotě jeho pramenů v kontextu studia raně středověkého hradu Praha - Das archäologische Areal unter dem III. Hof der Prager Burg. Bemerkungen zur Bedeutung und Aussagekraft der Quellen im Kontext der frühmittelalterlichen Burg Prag, AR LI, 692-714.

- 2001: Das archäologische Areal auf dem III. Hof der Prager Burg und seine Bedeutung für die Erforschung der Chronologie Mittelböhmens im frühen Mittelalter. In: Velká Morava mezi východem a západem (Galuška, L.-Kouřil, P.-Měřínský, Z., edd.), 69-75. Uherské Hradiště.

-2008: Dalších deset let archeologického areálu pod třetím nádvořím Pražského hradu - Weitere zehn Jahre Ausgrabungsfeld unter dem dritten Burghof der Prager Burg, ZPP 65, 259-263.

- 2009: Praha 1-Hradčany. Pražský hrad - III. nádvoří. Sonda 20/1996 a 2/1998 záchranný a revizní výzkum v souvislosti s rekonstrukcí nosné desky. Nálezová zpráva ARÚ AV ČR, čj. 14045/09.

- 2011: Dřevěné konstrukce a využití dřeva v raně středověké opevněné centrální lokalitě. Př́ílady z Pražského hradu - Wooden structures and the use of wood at an early medieval fortified central site. Examples from Prague Castle, PA CII, 355-400.

- 2011a: NKP Vyšehrad 2010-2011 - areál s kostelem sv. Vavřince, ppč. 99/2. Zpráva o archeologické části projektu sanace archeologického areálu realizované s pomocí prostředků Pražského archeologického fondu na základě smlouvy mezi Královskou kolegiátní kapitulou sv. Petra a Pavla na Vyšehradě a ARÚ AV ČR, Praha, v. v. i., a rozhodnutí MHMP z 4. 11. 2010.

- 2013: Replika dlažby vyšehradského typu v bazilice sv. Vavřince na Vyšehradě. Vícegenerační archeologický výzkum a současná prezentace archeologické památky, Staletá Praha 29, 114-125.

BOHÁČOVÁ, I.-KOZÁKOVÁ, R., 2008: Přírodní prostředí Pražského hradu a jeho zázemí - výpověd' pylové analýzy z raně středověkých sedimentů ze III. nádvoří - The natural environment of Prague Castle and its surroundings in the Early Middle Ages: Evidence provided by a pollen analysis of sediments from the Third courtyard, AR LX, 547-564

BOHÁČOVÁ I.-NECHVÁTAL, B., 2014: Historie a současná obnova archeologického areálu s bazilikou sv. Vavřince v prostoru NKP Vyšehrad - History and current renovation of the archeological complex of the St. Lawrence Basilica in Prague's Vyšehrad, ZPP 74, 3-11.

ČULÍKOVÁ, V., 1998: Rostlinné makrozbyky z raně středověkých sedimentů na III. nádvoří Pražského hradu - Pflanzliche Makroreste aus Frühmittelalterlichen Sedimenten im III. Burghof der Prager Burg, Archaeologica Pragensia 14, 329-341.

DVORSKÁ, J.-BOHÁČOVÁ, I., 1999: Das historische Holz im Kontext der archäologischen Untersuchungen der Prager Burg. In: Internationale Tagungen in Mikulčice. Band V. Probleme der mitteleuropäischen Dendrochronologie und naturwissenschaftliche Beiträge zur Talaue der March (Poláček, L.Dvorská, J., edd.), 55-67. Brno.

KAŠIČKA, F.-NECHVÁTAL, B., 1976: Otonská architektura na Vyšehradě a její rekonstrukce, Umění XXIV, 429-433.

KUNEŠ, P., 2012: Protokol - technologická laboratoř. 9-12 archeologický areál baziliky sv. Vavřince, Praha-Vyšehrad, popis a rozbor materiálu podlahy, podklad pro archeologický výzkum. Interní materiál. Praha: NPÚ ÚP, 2012, č. j. 302/8215/2011, ulož. v Archivu NPÚ Gř., Praha.

4 Za poskytnutí konzultace v tomto ohledu děkuji J. Podliskovi z NPÚ ÚOP v Praze. 
VARADZIN, L., 2009: Bazilika sv. Vavřince na Vyšehradě. Zhodnocení dosavadních archeologických výzkumů v bazilice a jejím okolí. In: Nechvátal, B. et al., Rotunda sv. Martina a bazilika sv. Vavřince na Vyšehradě, archeologický výzkum, 302-399. Praha.

VARADZIN, L.-NECHVÁTAL, B., 2012: Objev sakrální stavby překvapivého půdorysu pod bazilikou sv. Vavřince na Vyšehradě v r. 2011. Předběžná zpráva, PRP 19, č. 2, 170-176.

\section{Zusammenfassung}

Die Präsentation archäologischer Denkmäler in Tschechien. Archäologische Areale in situ am Beispiel der Prager Burg und des Vyšehrads (Prager Hochburg)

Die Präsentation der archäologischen Denkmäler an den beiden erstrangigen Prager Fundstellen Prager Burg (1929) und Vyšehrad (1934) zählt auch im gesamteuropäischen Maßstab zu den ältesten ihrer Art. Die Entstehung der Denkmäler erfolgte im Zusammenhang mit den Rettungsgrabungen, die auf der Prager Burg (III. Burghof 1925-1929 - K. Guth, J. Pasternak et al.) und auf dem Vyšehrad (Areal mit St. Laurentius-Basilika 1924-1926 - J. Böhm, M. Grbić; parallel dazu auch weitere Teilpräsentationen freigelegter Denkmäler) durchgeführt worden waren. Ihr Entstehungskonzept bestand im Wesentlichen 1) aus der Stabilisierung ausgewählter archäologischer Objekte in situ, in Ausnahmefällen dann darin, sie in situ herauszunehmen und anschließend an einen anderen Ort zu bringen (Abb. 1), 2) in der Bemühung, den breiteren Fundraum und im Falle der Prager Burg auch den stratigraphischen Kontext dieser Denkmäler zu erhalten und zu präsentieren, 3) im schonenden Umgang mit den archäologischen Objekten (Minimierung zerstörerischer Eingriffe, Minimierung konservierender Eingriffe), 4) in der Bemühung, der breiten Öffentlichkeit und dem Fachpublikum einen authentischen Eindruck zu vermitteln, 5) in Professionalität und fachübergreifender Kooperation (technische Lösungen unter Heranziehung der modernsten, heute verfügbaren Verfahren und der fundierten Erfahrungen von Fachleuten). Beide Areale sind nicht nur durch ihre Bedeutung hinsichtlich der Außergewöhnlichkeit der in ihnen bewahrten Denkmäler und hinsichtlich der Denkmalpflege des unbeweglichen kulturellen Erbes miteinander verbunden, sondern auch durch die Tatsache, dass sie auch heute noch eine neue Erkenntnisquelle von außerordentlicher Bedeutung darstellen. Beide Areale haben auf Initiative des archäologischen Instituts der Akademischen Wissenschaften der Tschechischen Republik Prag, v. v. i., in den letzten Jahren eine Sanierung durchgemacht, die ihre weitere Existenz sicherte, die grundsätzliche Vorgehensweise bei ihrem zukünftigen Schutz festlegte und gleichzeitig eine neue Nutzung ihres Aussagepotenzials möglich machte. An den aufgeführten Beispielen wird deutlich, dass das Wesentliche einer Präsentation archäologischer Denkmäler in situ noch nicht einmal so sehr auf der Qualität des Vorhabens und des Präsentationsprojektes beruht, sondern vor allem auf ihrer Aufrechterhaltbarkeit, d.h. auf der Gewährleistung einer regelmäßigen und präventiven Pflege der erhaltenen Denkmäler, auf einem sytematischen Monitoring der Klima- und Materialänderungen, sowie darauf, einem Zerfall der Denkmäler zuvorzukommen, und zwar nicht nur mit der Perspektive über eine Generation an „Ausgräbern“ von Denkmälern, Entwicklern bzw. Umsetzern von Projekten, sondern auf der Zeitebene einer longue durée. Dabei geht es freilich nicht nur um die Frage der finanziellen Gewährleistung und einer entsprechenden professionellen Sachkundigkeit, sondern auch um die Frage einer möglichen kontinuierlichen Verantwortlichkeit des Eigentümers bzw. Verwalters eines Denkmals. Es ist offenkundig, dass dabei noch nicht einmal der Staat oder eine andere öffentliche Institution Garant für Kontinuität und optimale Lösungen sein muss, da auch deren Entscheidungen über ein bereits existierendes Denkmal und dessen Zukunft jederzeit von äußeren Einflüssen und Ereignissen beeinflusst werden können, seien sie nun wirtschaftlicher oder politischer Art. Häufig kann das Schicksal eines Denkmals dann auch von der Initiative und dem Erfindungsgeist eines Einzelnen sowie von dessen subjektiven Wertmaßstäben abhängig sein. Eine der Lösungen, mit welcher eine langfristige Erhaltung von archäologischen Denkmälern 
in situ ${ }^{5}$ gewährleistet werden kann, besteht in heutiger Zeit allein darin, die präsentierten Denkmäler zum kulturellen Erbe oder zu archäologischen Denkmalschutzgebieten erklären zu lassen, und zwar zu klar festgelegten Bedingungen, die ihre regelmäßige, detaillierte und professionelle Kontrolle und Instandhaltung garantieren.

Der vorliegende Beitrag wurde im Rahmen des Projektes mit der Registriernummer 13P01OVV014 des Kulturministeriums der Tschechischen Repubik ausgearbeitet.

PhDr. Ivana Boháčová, Ph.D., Archeologický ústav AV ČR, Praha, v. v. i., Letenská 4, 11801 Praha 1, Česká republika, bohacova@arup.cas.cz 
